ВІСНИК

ОДЕСЬКОГО НАЦІОНАЛЬНОГО

МОРСЬКОГО УНІВЕРСИТЕТУ
HERALD

OF THE ODESSA NATIONAL

MARITIME UNIVERSITY № 2 (65), 2021

УДК 94 / 629.5

DOI 10.47049/2226-1893-2021-2-12-46

\title{
О НАУЧНО-ПРАКТИЧЕСКОМ НАСЛЕДИИ ПРОФЕССОРА ГЕННАДИЯ ВЯЧЕСЛАВОВИЧА ЕГОРОВА
}

\author{
А.Г. Егоров \\ к.т.н., генеральный директор \\ Морское инженерное бюро, Украина, Одесса
}

Показан путь становления профессора, доктора технических наук, лауреата Государственной премии, члена экспертного совета ВАК Г.В. Егорова как видного ученого и практика в области проектирования судов, судостроения, судоремонта и судоходства. Описаны основные научно-практические результаты деятельности профессора Г.В. Егорова.

Отдельно отмечены основные шаги, предпринятые Г.В. Егоровым для развития отрасли, включая историю создания Морского Инженерного Бюро, главные научные работы, направленные на повышение эффективности работы существующего флота, безопасность мореплавания и создание концептов судов различного назначения нового поколения.

За 26 лет существования по проектам руководимого профессором Г.В. Егоровым Морского Инженерного Бюро было построено более 420 судов, огромное количество судов было модернизировано и переоборудовано. Написано более 1000 актуальных научных работ.

Представлены итоги деятельности профессора Г.В. Егорова на международной арене.

Ключевые слова: Егоров Геннадий Вячеславович, история, влияние, анализ, проектирование, судоремонт, судостроение, судоходство.

УДК 94 / 629.5

DOI 10.47049/2226-1893-2021-2(65)-12-46

\section{ПРО НАУКОВО-ПРАКТИЧНУ СПАДЩИНУ ПРОФЕСОРА ГЕННАДІЯ В'ЯЧЕСЛАВОВИЧА ЄГОРОВА}

\author{
О.Г. Сгоров \\ к.т.н., генеральний директор
}

Морське інженерне бюро, Україна, Одеса

Показано шлях становлення професора, доктора технічних наук, лауреата Державної премії, члена експертної ради ВАК Г.В. Сгорова як відомого вченого $і$ практика в області проектування суден, суднобудування, судноремонту та судноплавства.

(C) Егоров А.Г., 2021 
Окремо відзначені основні кроки, зроблені Г.В. Сгоровим для розвитку галузі, включаючи історію створення Морського Інженерного Бюро, головні наукові роботи, спрямовані на підвщщення ефективності роботи існуючого флоту, безпеку мореплавання $і$ створення концептів суден різного призначення нового покоління.

За 26 років існування за проектами керованого професором Г.В. Сгоровим Морського Інженерного Бюро було побудовано більше 420 суден, величезна кількість суден була модернізована і переобладнана. Написано більше 1000 актуальних наукових робіт.

Представлені підсумки діяльності професора Г.В. Сгорова на міжнародній арені.

Ключові слова: Сгоров Геннадій Вячеславович, історія, вплив, аналіз, проектування, судноремонт, суднобудування, судноплавство.

UDC 94 / 629.5

DOI 10.47049/2226-1893-2021-2-12-46

\title{
ABOUT SCIENCE-PRACTICAL HERITAGE OF PROFESSOR GENNADIY EGOROV
}

\author{
A. Egorov \\ Candidate of Technical Sciences, General Director \\ Marine Engineering Bureau, Ukraine, Odessa
}

The way of formation Professor, Doctor of technical sciences, Laureate of the State Prize, Member of the Expert Council of the Higher Attestation Commission Gennadiy Egorov as highly respected scientist and practitioner in the field of ship design, shipbuilding, ship repair and shipping has shown. Main scientific and practical achievements of Professor Gennadiy Egorov have been described.

Main steps taken by Gennadiy Egorov for the development of the industry, including history of creation of Marine Engineering Bureau, main scientific works focused on increasing the efficiency of existing fleet, safety of navigation and creation of new generation vessels' concepts of various purposes.

For 26 years of existence, according to managed by Professor Gennadiy Egorov projects of Marine Engineering Bureau, more than 420 vessels have been built, huge number of vessels have been modernized and reequipped. More than 1000 essential scientific works have been written.

The achievements of Professor Gennadiy Egorov on international arena also have been presented.

Keywords: Egorov Gennadiy, history, influence, analysis, design, ship repair, shipbuilding, shipping. 
Постановка проблемы. 30 мая 2021 года не стало Геннадия Вячеславовича Егорова - создателя Морского Инженерного Бюро, идеолога, вдохновителя, главного мотора судостроительной отрасли, и просто замечательного, доброго, жизнерадостного и умного Человека.

Профессор Г.В. Егоров ушел из жизни на пике своей профессиональной карьеры, в самолете над Нижним Новгородом, над городом, в котором было построено (и строится до сих пор) наибольшее количество судов, спроектированных Морским Инженерным Бюро под личным руководством Геннадия Вячеславовича, - более 130.

Г.В. Егоров создал себя сам с нуля, тем ценнее результаты его деятельности. Всегда всем старался помочь, подсказать, посоветовать. Помимо полного погружения в судостроение и судоходство Геннадий Вячеславович увлекался историей, религией и техникой: мог часами читать лекции о древних цивилизациях, дискутировать на различные религиозные темы и обсуждать технические характеристики.

Под управлением профессора Г.В. Егорова Бюро прошло путь от небольшой фирмы, занимающейся исключительно расчетными задачами по корпусу судна и научными исследованиями по заказу классификационных обществ, до организации, выполняющей практически весь спектр инжиниринговых работ для судоходства и судостроения.

Целью статьи является оценка влияния научно-технической деятельности профессора Г.В. Егорова на отечественное проектирование, судостроение и судоходство.

Изложение основного материала. Геннадий Вячеславович родился 23 марта 1966 года в городе Одессе в семье военного моряка (см. рисунок 1), детство провел по месту службы отца - в Вилючинске.

Там же впервые познакомился с кораблями и судами и пошел в начальную школу. Как сам вспоминал Геннадий Вячеславович на одном из вебинаров, проведенных им в 2020 году, детское время оставило очень сильный отпечаток на формировании собственной личности как инженера-кораблестроителя в будущем.

К слову, в декабре 2020 года было сдано в эксплуатацию первое, построенное за последние 30 лет на отечественных верфях, грузопассажирское судно проекта PV22 «Адмирал Невельской» на 146 каютных пассажиров для Сахалина и Курил (см. рисунок 2) [1]. Геннадий Вячеславович очень гордился этим судном, для него оно имело особый смысл. По словам профессора Г.В. Егорова адмирал Геннадий Иванович Невельской был для него кумиром детства: он много читал о нем, они были тезками, ну а в-третьих, когда живешь на Камчатке, выдающийся исследователь Дальнего Востока гораздо ближе по духу, чем когда ты живешь в Европейской части. 


\begin{tabular}{c|c} 
ВІСНИК & HERALD \\
ОДЕСЬКОГО НАЦІОНАЛЬНОГО & OF THE ODESSA NATIONAL \\
МОРСЬКОГО УНІВЕРСИТЕТУ & MARITIME UNIVERSITY \\
№ $2(65), 2021$ & № 2 (65), 2021 \\
\hline \hline
\end{tabular}

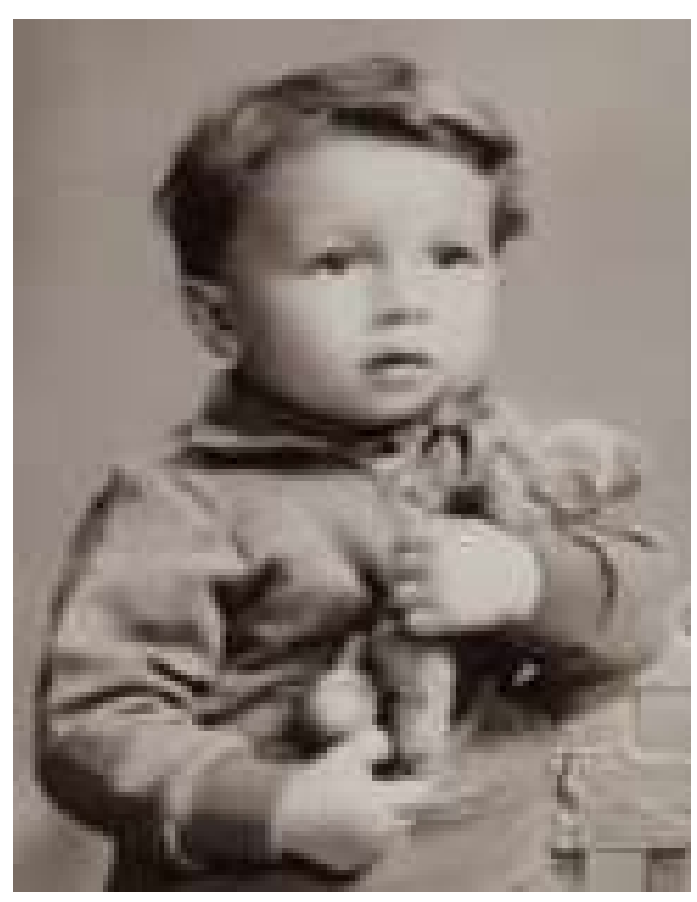

Рис. 1. Егоров Геннадий Вячеславович в детстве

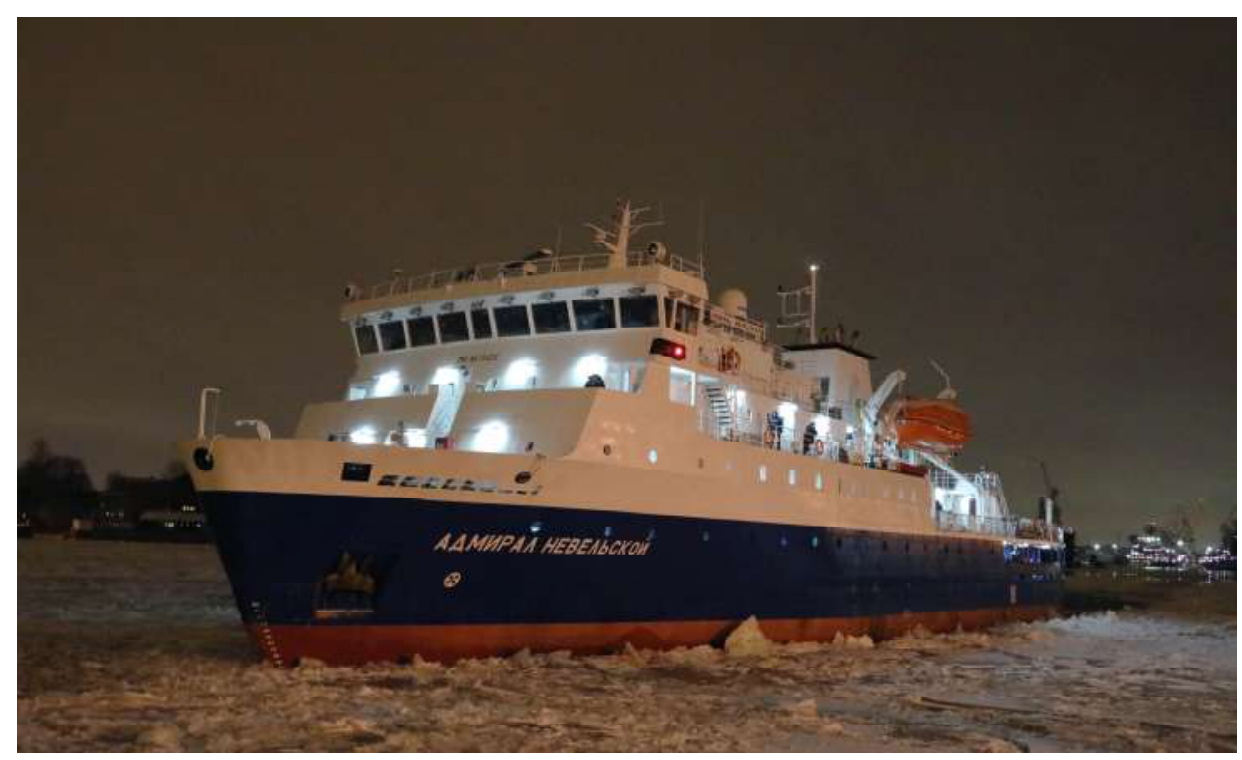

Рис. 2. Сданное в декабре 2020 года

морское грузопассажирскоесудно «Адмирал Невельской»

Автор фотографии - Иван Бородулин 
ВІСНИК

ОДЕСЬКОГО НАЦІОНАЛЬНОГО

МОРСЬКОГО УНІВЕРСИТЕТУ № 2 (65), 2021
HERALD

OF THE ODESSA NATIONAL

MARITIME UNIVERSITY № 2 (65), 2021

Общее среднее образование получал уже в Одессе: окончил с отличием школу № 4 в 1982 году.

Далее Геннадием Вячеславовичем планировалось поступление совершенно в другой институт, на иной факультет, никак не связанный с морем. Сдав вступительные экзамены на высочайшие результаты, и имея отличнейшую характеристику, выяснилось, что в год поступления убрали набор из Одессы...

Было принято решение поступать в Одесский Институт Инженеров Морского Флота (ОИИМФ) на кораблестроительный факультет.

Уже тогда начал раскрываться талант Геннадия Вячеславовича. Будучи человеком образованным, целеустремленным, талантливым, упорным, с огромнейшей силой воли, Г.В. Егоров со второго курса совмещал работу на кафедре строительной механики корабля с учебой и саморазвитием (см. рисунок 3). Причем сессии закрывал досрочно, заочно готовившись к экзаменам. Не ходил на лекции, чем очень сильно удивлял, а некоторых преподавателей, и раздражал.

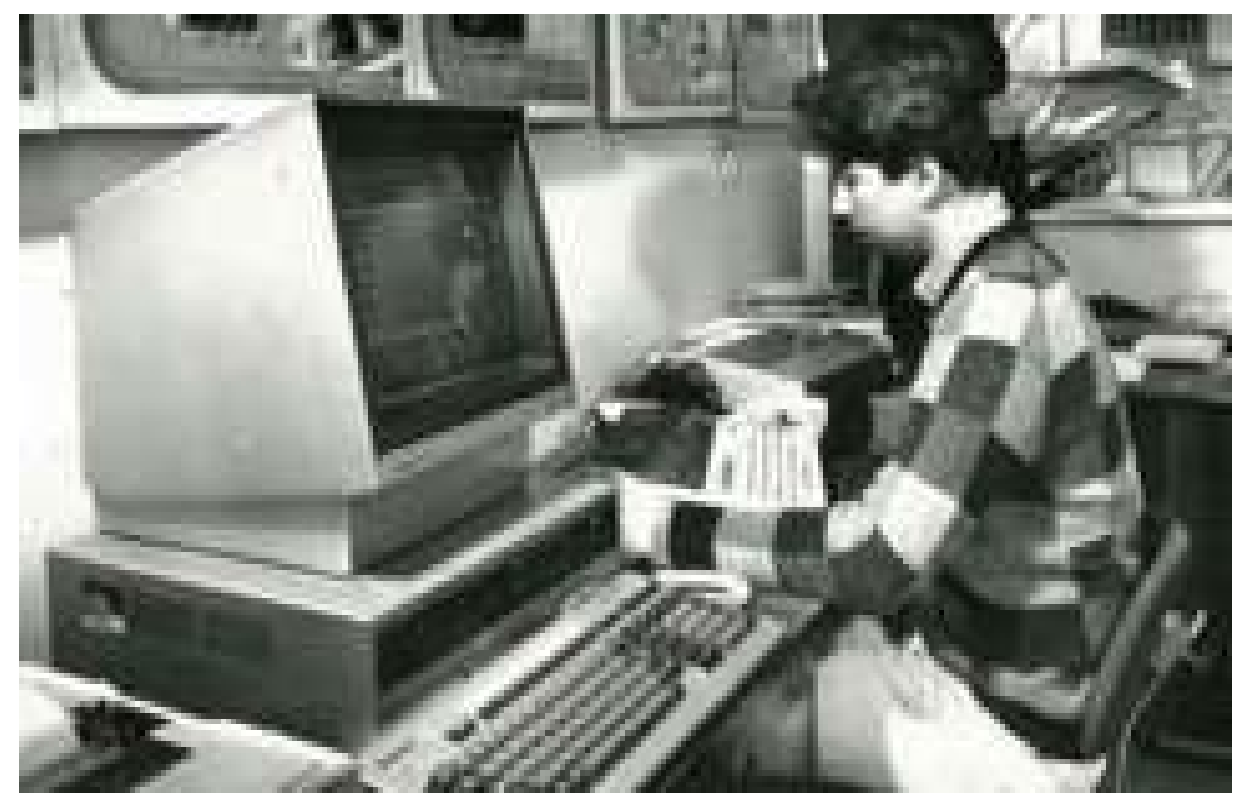

Рис. 3. Геннадий Егоров в работе

на кафедре строительной механики корабля ОИИМФ

Своим учителем Геннадий Егоров называл профессора Виталия Васильевича Козлякова, выдающегося ученого с мировым именем, последнего представителя старшего поколения советских прочнистовкорабелов, который в 1986-1996 годах был заведующим кафедрой строительной механики корабля (см. рисунок 4). 


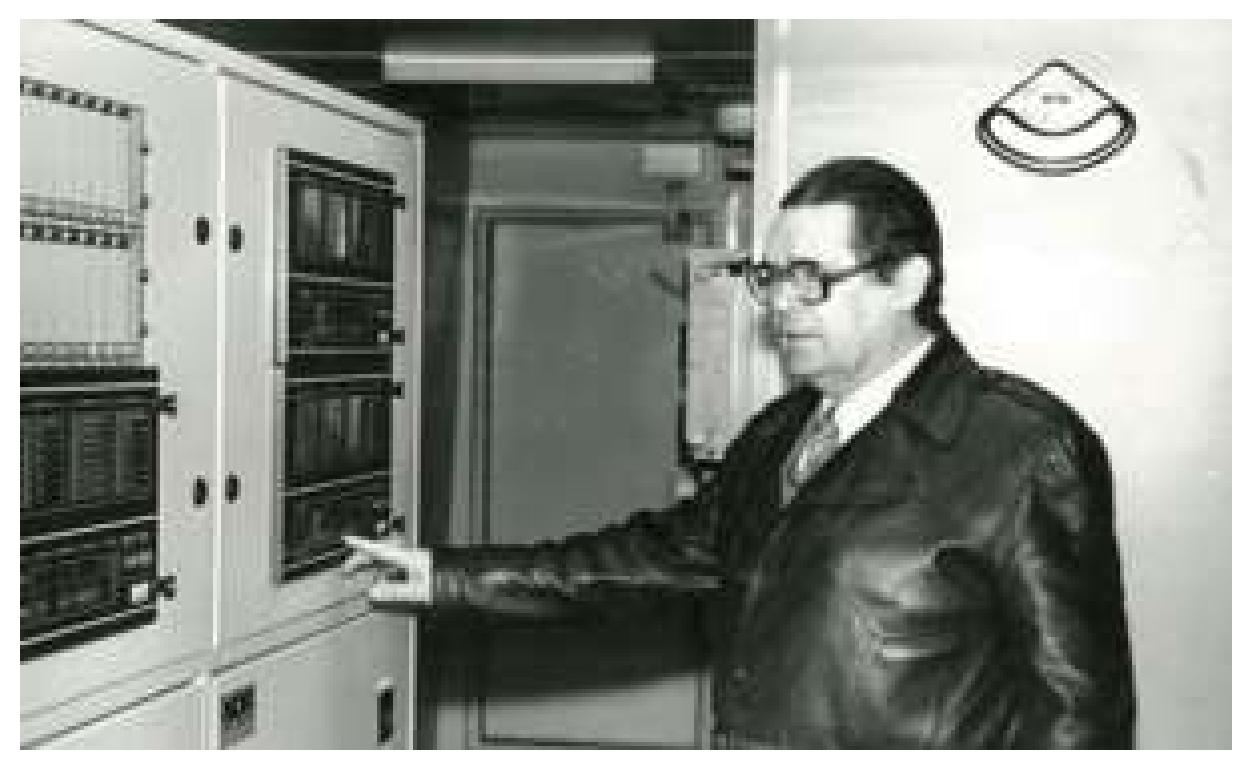

Рис. 4. Профессор В.В. Козляков, учитель профессора Г.В. Егорова

Плавпрактику проходил на судах ЧМП, ходил в рейсы по всему миру, включая североамериканский регион.

В 1988 году с «красным» дипломом завершил обучение в ОИИМФ по специальности «Судостроение и судоремонт», защитив дипломный проект на тему: «Разработка программ оптимизации грузового плана т/х «Александр Огнивцев» для персональной ЭВМ».

Геннадий Вячеславович в 1992 году закончил аспирантуру ОИИМФа на кафедре «Строительная механика корабля», результатом обучения в аспирантуре стала защита кандидатской диссертации на тему «Разработка методов оптимизации прочностных решений при эксплуатации судов» в 1993 году [2].

На защиту кандидатской диссертации были вынесены следующие научные положения:

- методика определения перерезывающих сил и изгибающих моментов на тихой воде в произвольном сечении по длине судна при произвольной посадке и реальной загрузке при наличии минимума исходной информации по корпусу;

- универсальная методика оценки изменений элементов изгиба корпуса судна на тихой воде с применением единичных эпюр соответствующих элементов изгиба;

- оценка влияния гибкости и потери жесткости на посадку и элементы изгиба поврежденного судна на тихой воде;

- методика прогнозирования мореходно-прочностных параметров судна в процессе грузовых операций с заданием шага изменения нагрузки 
(шага контроля) с учетом фактических производительностей грузовых и балластных операций;

- комплексный подход к борьбе за живучесть с учетом требований обеспечения общей продольной прочности на основе анализа статистики аварийных повреждений корпусов морских судов и исследования факторов, влияющих на несущую способность поврежденного корпуса судна;

- алгоритмы оптимального размещения однородных грузов, оптимальной балластировки судов, спрямления поврежденного судна, расчета снятия с мели крупнотоннажного судна с учетом требований остаточной прочности методами сепарабельного программирования.

Разработаны пакеты программ на ЭВM: пакет программ «SHIP» расчетного контроля, прогнозирования и оптимизации технических решений при эксплуатации и борьбе за живучесть корпусов морских транспортных судов для бортовых ПЭВМ; пакет программ «Корабелла» (программа расчета усилий и прогибов на тихой воде с учетом гибкости корпуса «СигМент», программа расчета усилий на тихой воде при минимуме исходных данных по корпусу «СигМА», новая версия программы расчета геометрических характеристик неповрежденных и поврежденных поперечных сечений корпусов «ЭльБрус») [2].

С 1993 год по 1995 год работал старшим научным сотрудником, преподавателем кафедры «Строительная механика корабля» ОИИМФ.

Совмещая работу на кафедре с учебой, Геннадий Егоров часто ездил в командировки, в судоходные компании, на заводы, где проявился еще один важный и фундаментальный талант - умение общаться с заказчиками, который впоследствии и лег в основу успешного создания, развития и процветания Морского Инженерного Бюро.

В 1995 году учредил Морское Инженерное Бюро в Одессе, а в марте 2000 года аналогичную фирму в Санкт-Петербурге. При этом никогда не забывал и всегда поддерживал родной институт, организовал совместно с выпускниками кораблестроительного факультета ОИИМФ Хаджишвили Шотой Гурамовичем (компания «Рисоил») и Масловым Сергеем Ивановичем (компания «Сиго-Марин») грандиозный по своим масштабам столетний юбилей кораблестроительного факультета в 2018 году [3] (см. рисунок 5). До конца своих дней был главой наблюдательного совета Одесского национального морского университета (ОНМУ, ранее ОИИМФ).

Продвигая работу Бюро на международной арене, 5 декабря 2016 года в Баку Геннадий Вячеславович создал совместное с Азербайджанским Каспийским Морским Пароходством предприятие «Каспийское Морское Инженерное Бюро». Документы по созданию новой проектной организации подписали от Азербайджанского Каспийского Председатель Пароходства Рауф Велиев и от Морского Инженерного Бюро генеральный директор Бюро, профессор, доктор технических наук Геннадий Егоров (см. рисунок 6). 


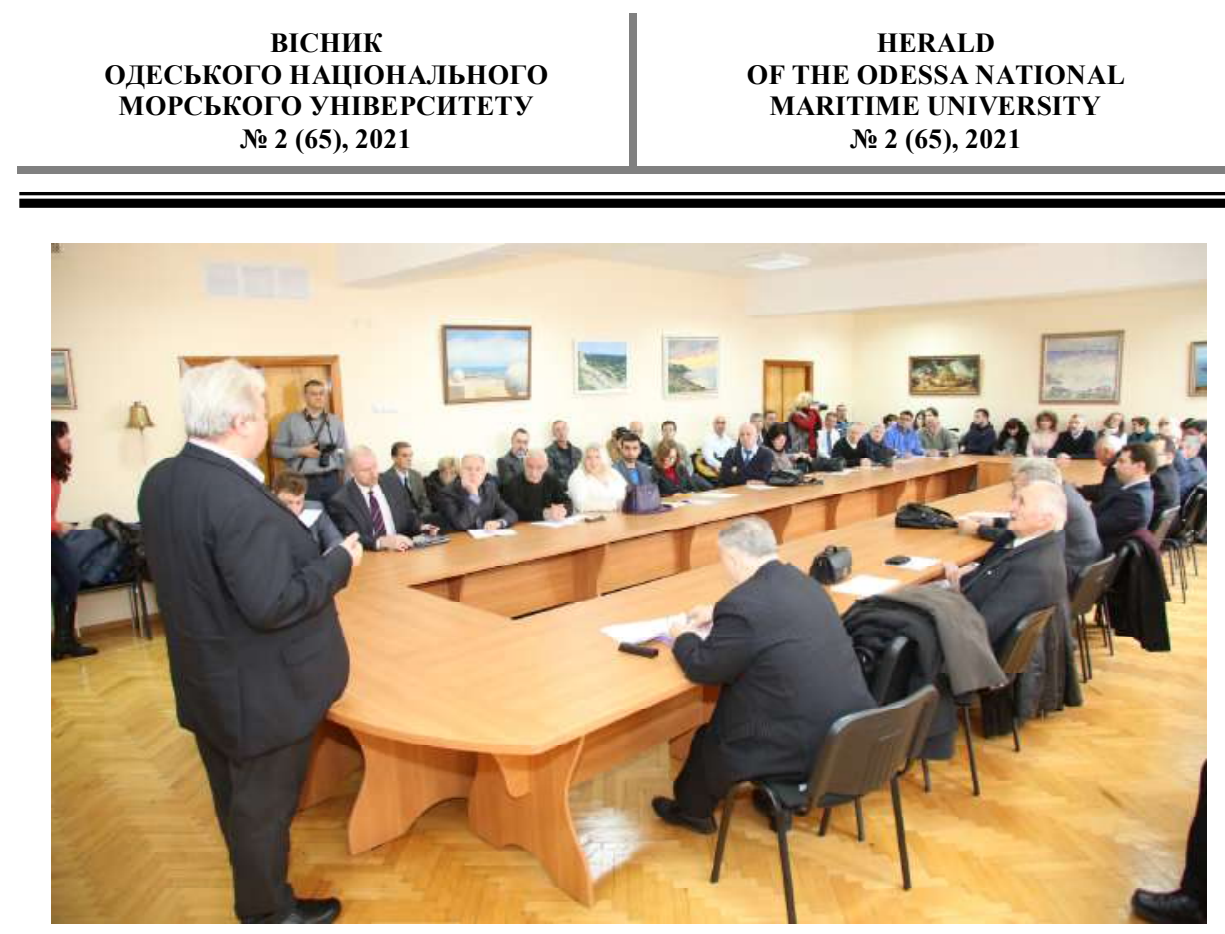

Рис. 5. Профессор Г.В. Егоров выступает на международной научно-технической конференции «Столетие высшего кораблестроительного образования в Украине», организованной и проведенной в рамках мероприятий по празднованию

100-летнего юбилея кораблестроительного факультета

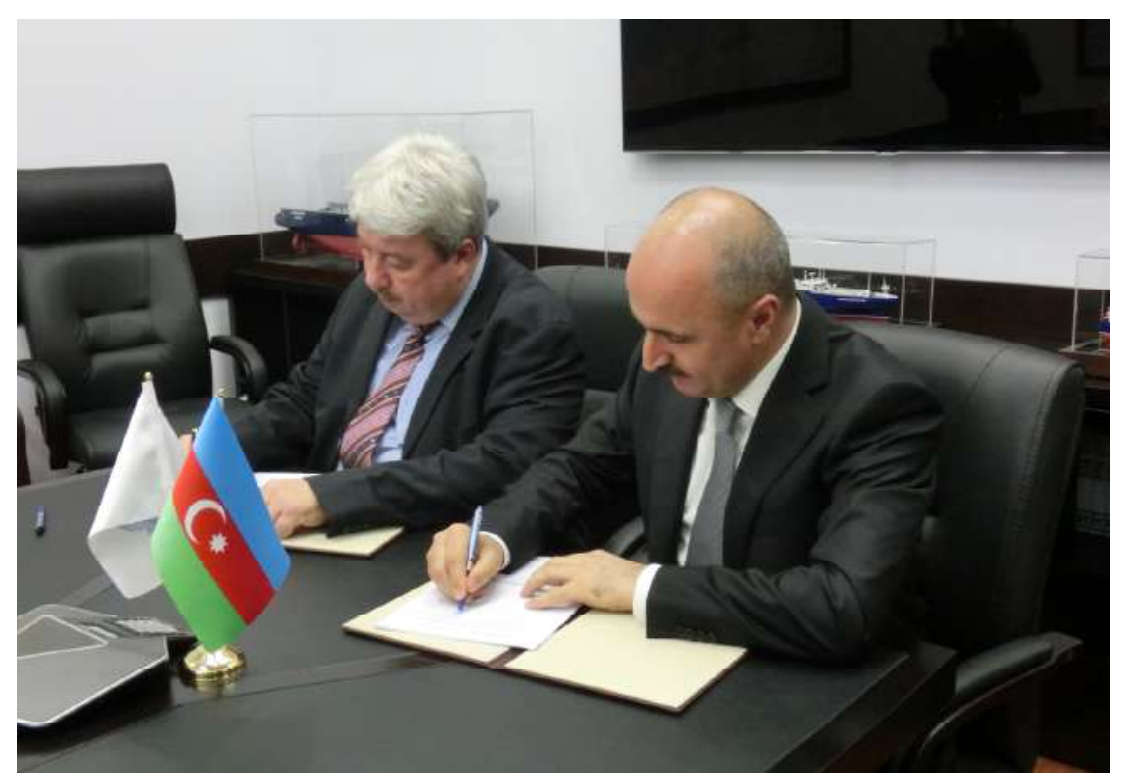

Рис. 6. Торжественное подписание документов Совместного Предприятия «Каспийское Морское Инженерное Бюро» в Азербайджане 
ВІСНИК

ОДЕСЬКОГО НАЦІОНАЛЬНОГО

МОРСЬКОГО УНІВЕРСИТЕТУ

№ 2 (65), 2021
HERALD

OF THE ODESSA NATIONAL

MARITIME UNIVERSITY № 2 (65), 2021

Результатами совместной деятельности компаний стали автомобильно-железнодорожные-пассажирские паромы проекта CNF18C (см. рисунок 7 и 8), танкеры-химовозы проекта RST12C, танкер-музей проекта HS01.

С первых дней появления Морского Инженерного Бюро, его высокопрофессиональные разработки и нестандартные инженерные решения получили поддержку и признание ведущих специалистов Российского Морского Регистра Судоходства. Геннадий Вячеславович был членом Президиума НТС Российского Морского Регистра Судоходства.

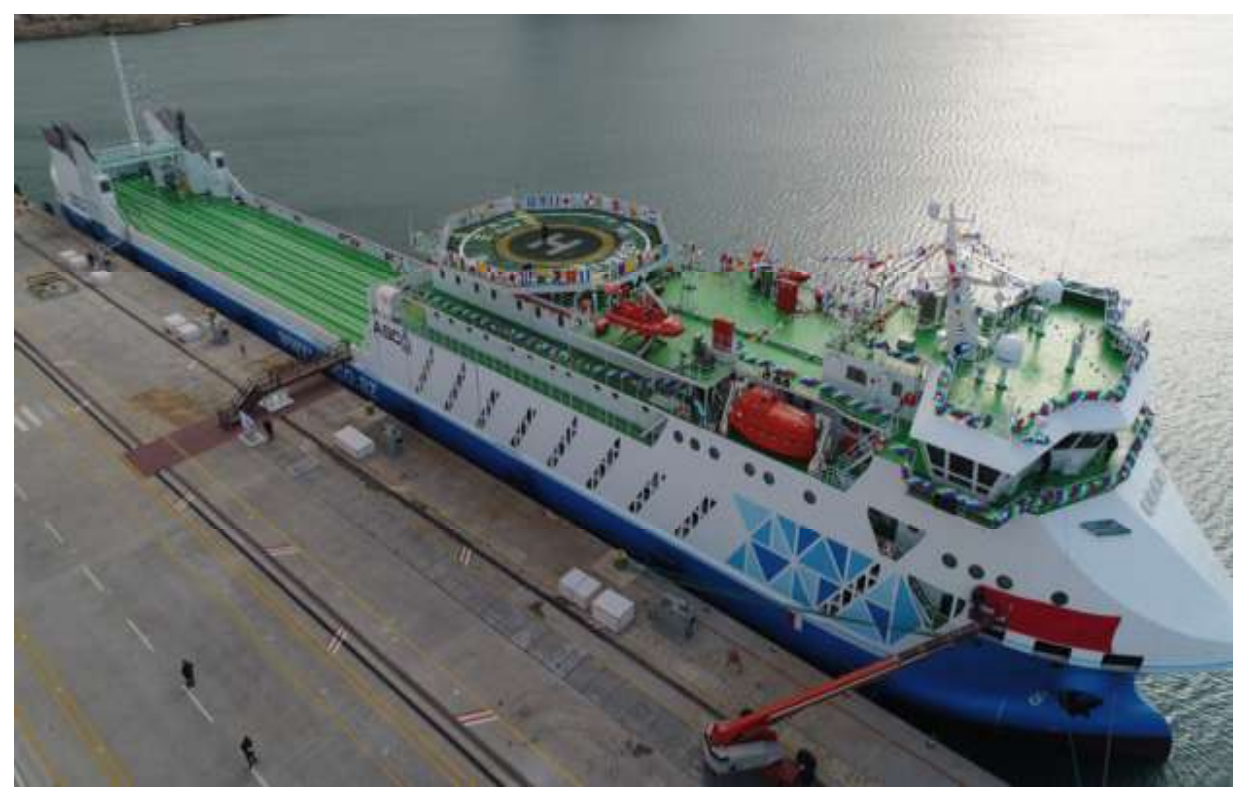

Рис. 7. Торжественная цุеремония сдачи в эксплуатащию автомобильно-железнодорожного-пассажирского парома проекта CNF18C «Азербайджан» на Бакинском заводе 1 марта 2021 года в присутствии Президента Азербайджанской Республики Ильхама Алиева и первой леди Мехрибан Алиевой

Благодаря Геннадию Вячеславовичу, с 1998 года значительно укреплены рабочие и научные контакты с Российским Речным Регистром. Он был членом Президиума НТС Российского Речного Регистра.

Работа с Госфлотнадзором Украины, а затем и с Регистром Судоходства Украины, как его преемником, всецело было ориентирована на поддержку отечественных судовладельцев, в том числе и на продление сроков службы существующего флота [4]. Являлся членом НТС Регистра Судоходства Украины. 


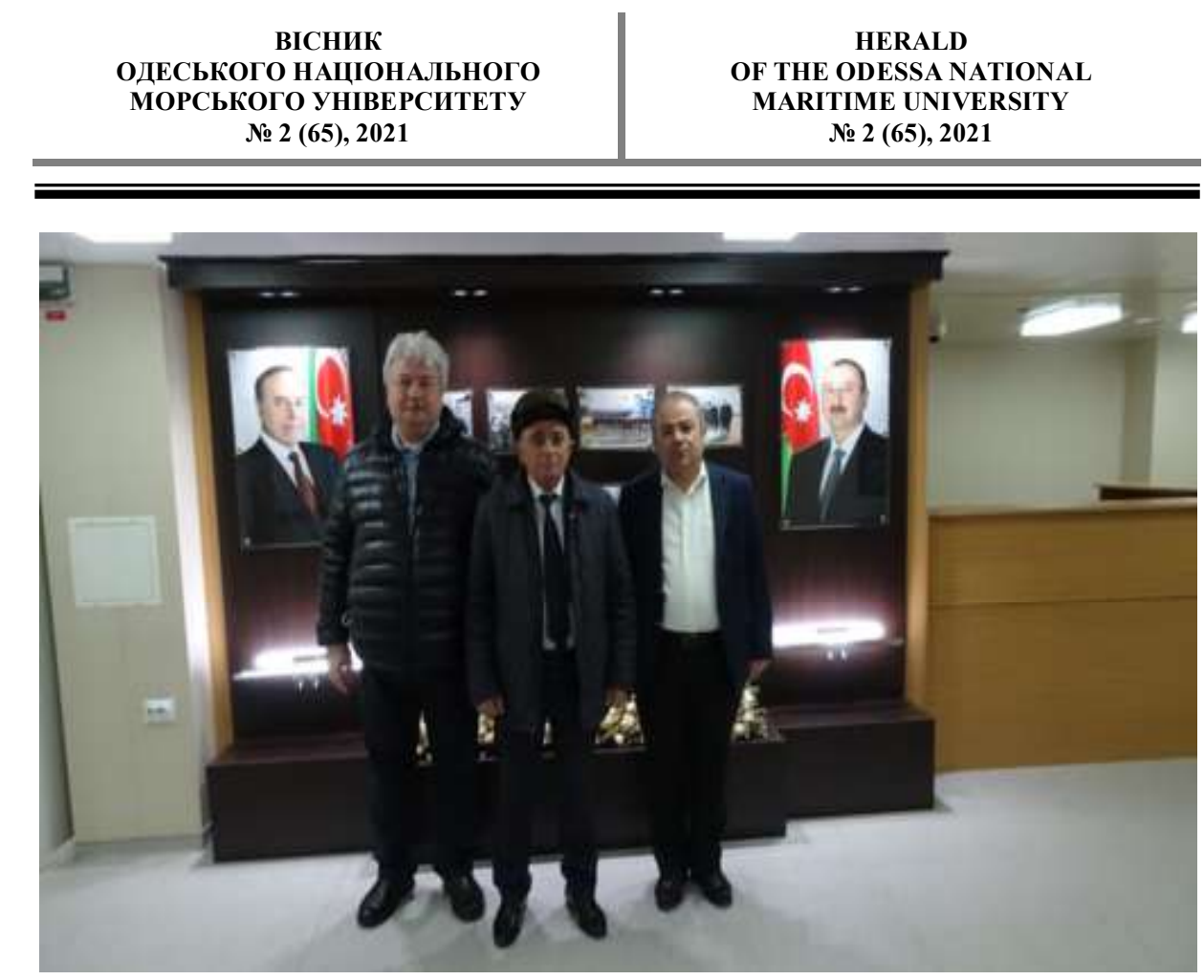

Рис. 8. Профессор Г.В. Егоров с генеральным директором Бакинского завода Иманверды Хасановым и генеральным директором НИИ «Каспморпроект» и Каспийского морского инюенерного бюро Ойрадом Абдуллаевым на борту автомобильно-железнодорожногопассажсирского парома проекта CNF18C «Азербайджан»

Награжден различными наградами, знаком «За заслуги» Российского Морского Регистра Судоходства, знаком «Почетный работник Российского Речного Регистра», знаком «Почетный работник Регистра Судоходства Украины».

В первые четыре года своего существования Бюро занималось исключительно расчетными задачами по корпусу судна и научными исследованиями по заказу классификационных обществ: разрабатывались проекты модернизации, реклассификации, реновации, повышения грузоподъемности и расширения районов плавания, выполнялись расчеты прочности и подкреплений, корректировались Правила по накопленному эксплуатационному опыту и т.п. [5; 6]. Все эти работы были направлены на повышение эффективности работы судовладельцев. Бюро работало на результат.

Плодотворная работа Геннадия Вячеславовича с Украинским Дунайским Пароходством (на то время Председателем Правления УДП был Суворов Петр Семенович) стала результатом строительства на Килийском СРЗ несамоходных судов проекта 1635 в различных модификациях (1635Т, 1635ТМ - нефтеналивные, 1635ОУ, 1635ОМДЛ, 16353М, 16353МК - сухогрузные). 
ВІСНИК

ОДЕСЬКОГО НАЦІОНАЛЬНОГО МОРСЬКОГО УНІВЕРСИТЕТУ № 2 (65), 2021
HERALD

OF THE ODESSA NATIONAL

MARITIME UNIVERSITY № 2 (65), 2021

Нацеленность на повышение безопасности эксплуатации и увеличение прибыли судовладельца-заказчика, умение общаться, слушать и предлагать эффективные решения, связывать практику и научные обоснования и расчеты Геннадием Вячеславовичем привели к знакомству с турецкой компанией «Палмали», которая предложила Морскому Инженерному Бюро создать собственный новый проект нефтеналивного судна смешанного плавания нового поколения: проект 005RST01 [7].

Разработке проекта 005RST01 предшествовала кропотливая работа по систематизации опыта эксплуатации существующих судов смешанного плавания и судов ограниченного плавания, работающих в других регионах, выявление основных проблемных вопросов. В августе 2002 года судостроительная верфь SELAH (Тузла, Турция) сдала «Палмали» головной танкер-продуктовоз смешанного плавания «Армада Лидер» (см. рисунок 9).

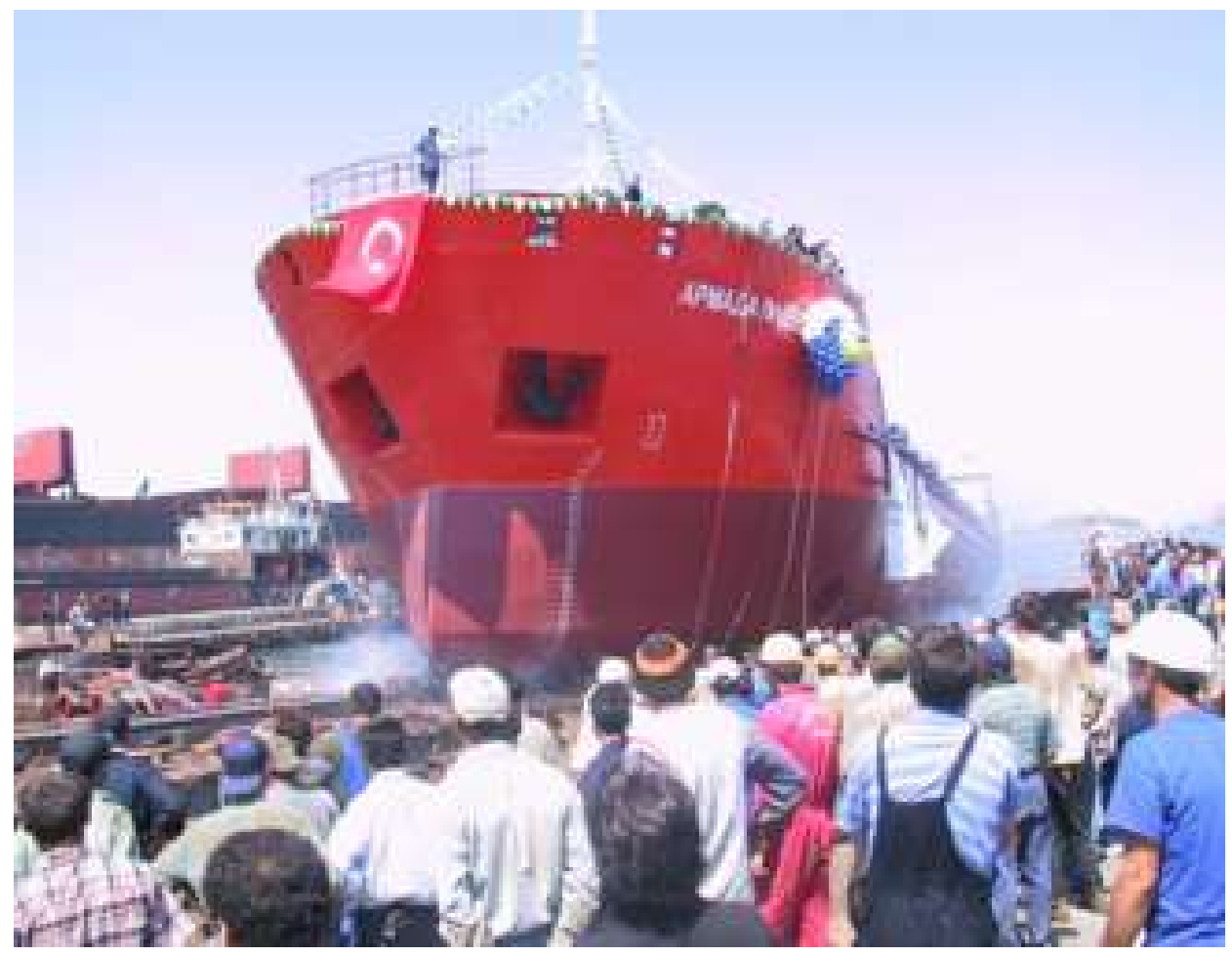

Рис. 9. Историческое событие - спуск на воду головного танкерапродуктовоза смешанного плавания «Армада Лидер» проекта 005RST01, первого судна, полностью спроектированного Морским Инженерным Бюро 
Особенностью судов типа «Армада» является использование в качестве единых средств движения и управления полноповоротных винто-рулевых колонок, отсутствие продольной переборки в ДП, применение погружных насосов в грузовой и балластной системах, полное отсутствие набора в грузовых танках, развитый тронк, коэффициент полноты 0,90 .

Большинство из принятых технических решений было впервые реализовано на судах смешанного плавания.

Так началась эпоха проектирования Морского Инженерного Бюро, которая вывела компанию на совершенно иной профессиональный уровень: под руководством Геннадия Вячеславовича было спроектировано более 100 реальных проектов (не концептов, концептов значительно больше), построено более 420 судов:

- сухогрузных судов речного, смешанного река-море и ограниченных морских районов плавания типа «Пола Макария», «Нева-Лидер», «Герои Сталинграда», «Гейдар Алиев», «Мирзага Халилов», «Каспиан Экспресс», «Азов макс», «Карелия», «Челси», «Хазар», «Надежда», «Танаис», «Святой Георгий», «Оммакс», «Птичь», «Порт Оля», «Леда», «Единый», «Пола» и др.;

- танкеров-продуктовозов, танкеров-химовозов, танкеров-бункеровщиков типа «Лачин», «Балт-Флот», «ВФ Танкер», «Александр Шемагин», «Армада», «Новая Армада», «Астон», «Палойл», «Роскем», «Казань», «Экомаринер», «Рассвет», «МН», «Белмакс», «Святой князь Владимир», «Марлин», «Глостер» и др.;

- морских сухогрузных судов неограниченного района плавания типа «EMI Proud», «Аметист», «Спарта», «Саксона», «Скала», «Eren-C», «Кая Пионер»;

- многофункциональных ледоколов-снабженцев мощностью 22 МВт класса Icebreaker 8 типа «Александр Санников», многофункциональных аварийно-спасательных судов-ледоколов типа «Берингов Пролив» мощностью 7 МВт с классом Icebreaker 6, многофункциональных аварийно-спасательных судов арктического плавания типа «Спасатель Карев» мощностью 4 МВт с классом Arc 5, многофункциональных морских водолазных судов типа «Стольный град Ярославль»;

- больших кормовых морозильных траулеров типа «Баренцево море»;

- краболовов-процессоров типа «Зенит» и «Арктур»;

- буксиров, в том числе мелкосидящих ледокольных буксиров типа «Портовый», транспортных буксиров-снабженцев для Каспия типа «Феникс», пожарных буксиров типа «Пенай», буксиров-кантовщиков типа «Бульбаш»;

- железнодорожных паромов типа «Петровск», «Скиф», «Авангард», «Балтийск», «Славянин» и «Ulfat»; 
- автомобильно-пассажирских паромов и железнодорожноавтомобильных-пассажирских паромов типа «Азербайджан», морских грузопассажирских судов типа «Адмирал Невельской»;

- комбинированных танкеров-площадок типа «Балт Флот»; CET-C»;

- морских балкеров типа «Грумант», «ОВАНAN-C» и «BEH-

- накатных судов снабжения для Камчатки типа «Сосновка» и морских сухогрузных судов-площадок типа «Андрей Артеменко»;

- морских судов для перевозки скота;

- многофункциональных лоцмейстерских (обстановочных) судов типа «Дмитрий Сироткин», «Ладожский», «Виктор Кусков»;

- речных экологических судов типа «Эколог-1»;

- грунтоотвозных самораскрывающихся шаланд типа «КШ-1»;

- многофункциональный аварийно-спасательный катамаран типа «Игорь Ильин»;

- газовоз типа «Булмаркет»;

- музей-судно типа «Сураханы»;

- речных пассажирских круизных судов «Александр Грин», «Штандарт», «Мустай Карим»;

- прогулочных и служебно-разъездных судов типа «Империя», «Сочи», «Нева», «Барс», «Кавказ»;

- вертолетных площадок, плавучих причалов и специальных понтонов.

И продолжают строиться суда, в которые профессор Г.В. Егоров заложил свои идеи:

- 2 железнодорожных парома-газохода для Балтийского моря для линии Усть-Луга - Балтийск проекта CNF19M;

- железнодорожно-автомобильный-пассажирский паром для Каспийского моря проекта CNF18C;

- 2 автомобильно-железнодорожных пассажирских парома с ледовой категорией Arc 5 для паромной линии Ванино-Холмск проекта CNF11CPD;

- грузопассажирское судно пассажировместимостью 36 человек и дедвейтом около 1350 т для обеспечения сообщения Командорских островов и Северо-Курильска с Петропавловском-Камчатским проекта PV24; ского моря;

- 3 танкера-продуктовоза-химовоза проекта RST12C для Каспий-

- круизное пассажирское судно смешанного река-море плавания вместимостью 310 пассажиров проекта PV300VD;

- 3 многофункциональных аварийно-спасательных судна; CT-192;

- большие морозильные траулеры проектов КМТ01, КМТ02,

- краболовные суда-процессоры проектов КСП01, КСП02; 
ВІСНИК

ОДЕСЬКОГО НАЦІОНАЛЬНОГО МОРСЬКОГО УНІВЕРСИТЕТУ № 2 (65), 2021
HERALD

OF THE ODESSA NATIONAL

MARITIME UNIVERSITY № 2 (65), 2021

- 2 лоцмейстерских судна ледового класса для проведения работ на акватории портов Северного морского пути проекта BLV03; а также многие другие суда, включая современные морские и смешанного рекаморе плавания сухогрузные и нефтеналивные суда.

Многие из реализованных под руководством Геннадия Вячеславовича проектов были высоко оценены на международном уровне (см. таблицу 1).

Фактически, наиболее заметным явлением в отечественной воднотранспортной отрасли ХХІ века является массовая постройка необычных для всей практики мирового судостроения «сверхполных» танкеров смешанного плавания проекта RST27 (см. рисунок 10), созданных на их базе комбинированных судов (танкеров-площадок) проекта RST54, танкеровхимовозов проектов RST12C и RST27M, сухогрузных судов проекта RSD59 (см. рисунок 11) с коэффициентом общей полноты 0,932.

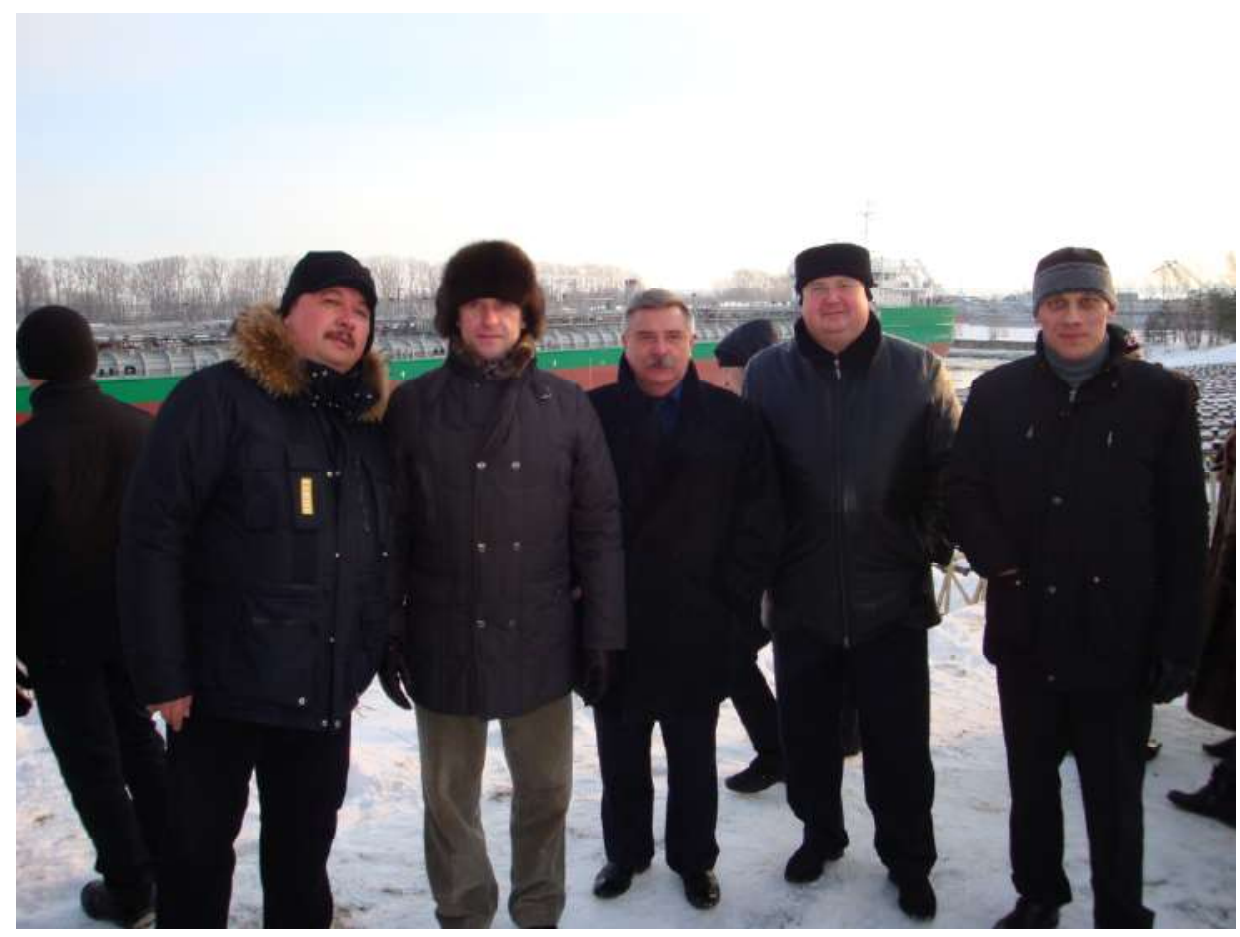

Рис. 10. Егоров Геннадий Вячеславович принимает участие в спуске на воду первого «сверхполного» танкера проекта RST27 17 февраля 2012 года на Красном Сормово 
Реализованные под руководством Геннадия Вячеславовича проекты, попавшие в список «Significant Ships» (в число 50 лучших судов года) Британского Королевского общества корабельных инженеров RINA

\begin{tabular}{|c|c|c|c|}
\hline $\begin{array}{c}\text { Год } \\
\text { награды }\end{array}$ & Проект & Количество судов по проектам & $\begin{array}{c}\text { Завод-строитель } \\
\text { награжденного судна }\end{array}$ \\
\hline \multirow{2}{*}{2007} & RSD17 & $\begin{array}{l}5 \text { сухогрузных судов в серии } \\
\text { дедвейтом } 6354 \text { т }\end{array}$ & Красное Сормово \\
\hline & RSD19 & $\begin{array}{l}4 \text { сухогрузных судна в серии } \\
\text { дедвейтом } 7004 \text { т }\end{array}$ & Волгоградский СС3 \\
\hline \multirow[b]{2}{*}{2012} & RST27 & $\begin{array}{l}42 \text { танкера в серии, построенных } \\
\text { на разных верфях, дедвейтом } \\
7030 \text { т }\end{array}$ & Красное Сормово \\
\hline & RSD49 & $\begin{array}{l}12 \text { сухогрузных судов в серии, } \\
\text { построенных на разных верфях, } \\
\text { дедвейтом } 7143 \text { т, одно судно } \\
\text { в постройке на «Лотосе» }\end{array}$ & Невский СС3 \\
\hline 2013 & RST25 & $\begin{array}{l}7 \text { танкеров в серии, построенных } \\
\text { на разных верфях, дедвейтом } \\
6710 \text { т, два судна в постройке на } \\
\text { «Лотосе» }\end{array}$ & Зеленодольский СС3 \\
\hline 2013 & RST27XC3 & $\begin{array}{l}42 \text { танкера в серии, построенных } \\
\text { на разных верфях, дедвейтом } \\
7030 \text { т }\end{array}$ & Херсонский СС3 \\
\hline 2014 & RST54 & $\begin{array}{l}7 \text { комбинированных } \\
\text { судов-танкеров-площадок в серии } \\
\text { дедвейтом } 5745 \text { т }\end{array}$ & Окская судоверфь \\
\hline 2017 & RST27M & $\begin{array}{l}5 \text { танкеров-химовозов в серии } \\
\text { дедвейтом } 7902 \text { т }\end{array}$ & Красное Сормово \\
\hline 2018 & RSD59 & $\begin{array}{l}43 \text { сухогрузных судна в серии, } \\
\text { построенных на разных верфях, } \\
\text { дедвейтом } 8144 \text { т, } 20 \text { судов в } \\
\text { постройке на Красном Сормово, } \\
\text { Окской судоверфи, Невском СС } 3\end{array}$ & Красное Сормово \\
\hline 2019 & RSD32M & $\begin{array}{l}8 \text { судов класса «Азовский } \\
\text { пятитысячник» дедвейтом } \\
5157 \text { тонн на характеристическую } \\
\text { осадку в море } 4,2 \text { м }\end{array}$ & Окская судоверфь \\
\hline 2019 & RST12C & $\begin{array}{l}\text { Танкер-продуктовоз-химовоз } \\
\text { дедвейтом } 7875 \text { тонн, еще } 3 \text { судна } \\
\text { строится }\end{array}$ & Бакинский СС3 \\
\hline 2020 & PV300 & $\begin{array}{l}\text { Первое, построенное за } 60 \text { лет на } \\
\text { отечественных верфях, речное } \\
\text { круизное пассажирское судно }\end{array}$ & Красное Сормово \\
\hline
\end{tabular}




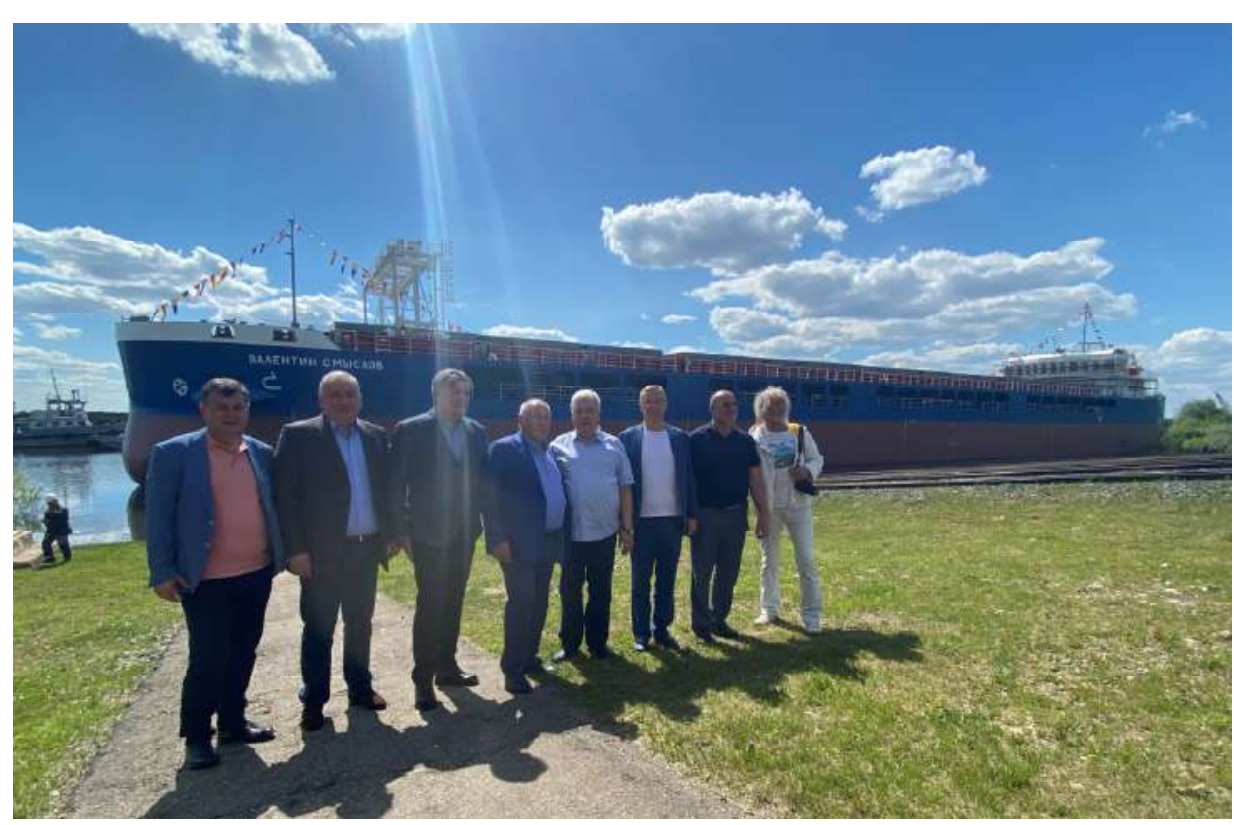

Рис. 11. Егоров Геннадий Вячеславович принимает участие в спуске на воду очередного сухогрузного судна смешанного плавания проекта RSD59 на Окской судоверфи. Последняя иеремония спуска, в которой принимал участие проф. Г.В. Егорова, 26 мая 2021 года

Однако не только увеличенный коэффициент полноты является особенностью этого нового поколения танкеров и сухогрузов, но и ряд других принципиально важных характеристик, также полученных под руководством проф. Г.В. Егорова в 2001-2021 годах в той или иной форме в научных исследованиях и использованных в новых концептах: обоснование главных размерений, выбора формы носовой и кормовой оконечностей, количества и типа движителей, способов формирования конструкции, особенностей архитектуры, снижения надводного габарита, нестандартного объединения функций судов, расширения типов предполагаемых к перевозке грузов и т.п.

Именно системный характер концептуального проектирования позволил дать такой заметный практический выход [8-16].

Полученные в эти годы теоретические результаты позволили Морскому Инженерном Бюро в 2011 году предложить экспертной группе международной транспортной группы UCL Holding, работавшей под руководством Ришата Багаутдинова, концепт танкера смешанного плавания «Волго-Дон макс» класса проекта RST27 типа «ВФ танкер» со «сверхполными» обводами с коэффициентом общей полноты 0,932. Такой танкер, сохраняя по району плавания класс R2 и возможность круглогодичной эксплуатации как у танкера типа «Армада», получил существенно 
увеличенную грузоподъемность в реке - дедвейт при осадке 3,60 м 5420 тонн (против 4700 тонн у проекта RST22 и у старых «Волгонефтей»), что сделало его уникальным речным судном при таком же дедвейте в море 7000 тонн, как у универсальных танкеров проектов RST22, RST22M более раннего поколения.

Таким образом, произошло редкое событие в современном отечественном гражданском судостроении, когда научный результат был получен самостоятельно и до появления конкретного заказа на постройку, а затем вполне успешно был реализован в виде большой серии судов.

Но в действительности это был вовсе не один шаг и не гениальное одномоментное предвидение, а вполне классическое научное исследование, с получением промежуточных выводов на каждом этапе научноисследовательской работы.

И такие системные исследования были выполнены под руководством Геннадия Вячеславовича для разных типов судов, были спроектированы целые линейки служебно-вспомогательных и технических, спасательных, пассажирских, рыбопромысловых судов и грузовых и грузопассажирских паромов нового поколения [17-25]. Большинство проектов реализовано на практике - построены суда, по некоторым разработанным проектам продолжается строительство.

Фактически, профессор Г.В. Егоров являлся «философом» судов нового поколения. По каждому из типов судов Геннадием Вячеславовичем был выполнен колоссальный объем работ по формированию концепции. Каждое судно из любой линейки детально обсуждалось с заказчиками и эксплуатантами.

Особое внимание профессор Г.В. Егоров уделял линейке пассажирских судов, практическими результатами реализации которой очень гордился - пассажирские суда проектов PV08, PV09, PV300 (см. рисунок 12), PV300VD.

Отдельной строкой следует отметить вклад Геннадия Вячеславовича не только в новое судостроение, но и в поддержку существующего флота. Продолжая работы по модернизации, переоборудованию, реновации, повышению грузоподъемности, начатые в 1995 году, Геннадий Вячеславович создал новый подход к сохранению флота: конверсии судов, строительство судов с использованием элементов судов-доноров [26-35]. Благодаря такому подходу, в тесном взаимодействии с РРP (на тот момент, генеральным директором был Ефремов Николай Андреевич) и РУ были построены сухогрузные суда типа «Челси» (см. рисунок 13) и других типов, железнодорожные паромы, нефтеналивные суда, пассажирские суда. 
ВІСНИК

ОДЕСЬКОГО НАЦІОНАЛЬНОГО

МОРСЬКОГО УНІВЕРСИТЕТУ

№ 2 (65), 2021
HERALD

OF THE ODESSA NATIONAL

MARITIME UNIVERSITY № 2 (65), 2021

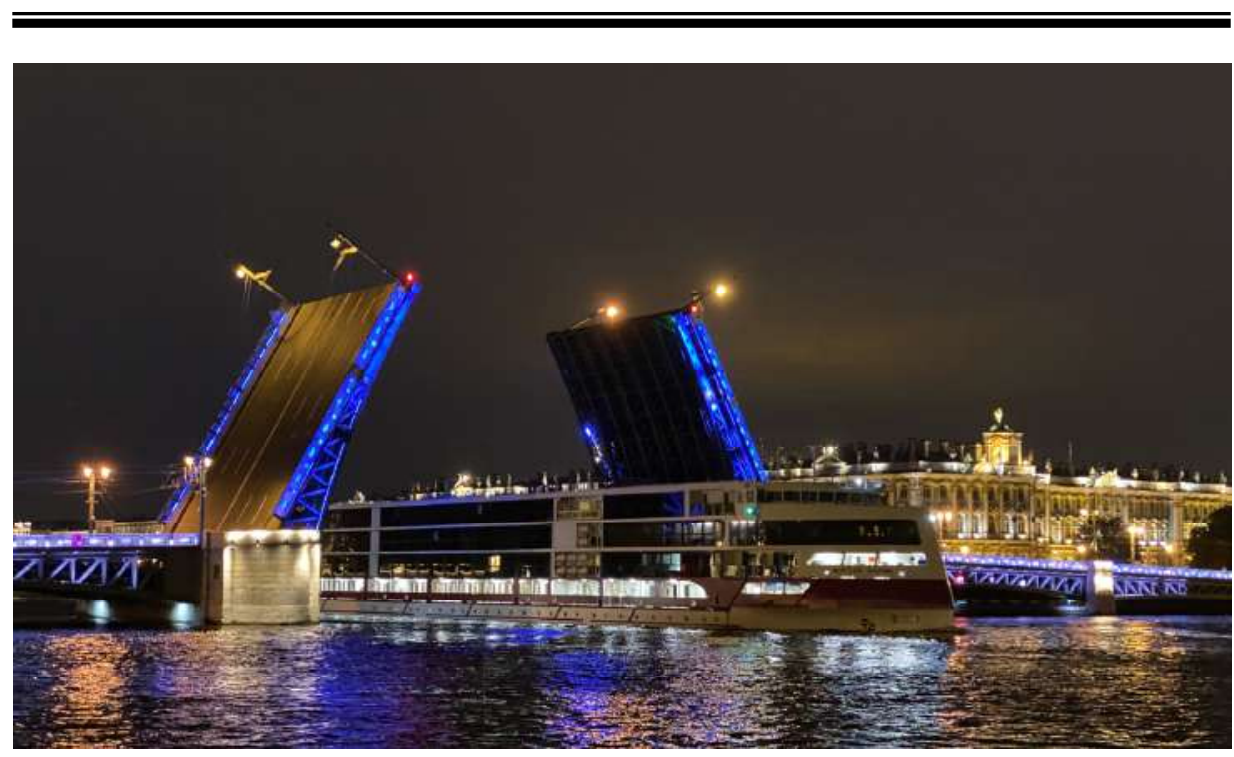

Рис. 12. Пассажирское судно проекта РV300 «Мустай Карим» проходит под разведенными мостами на Неве в Санкт-Петербурге с пассажирами на борту

Автор фотографии - Александр Соснин

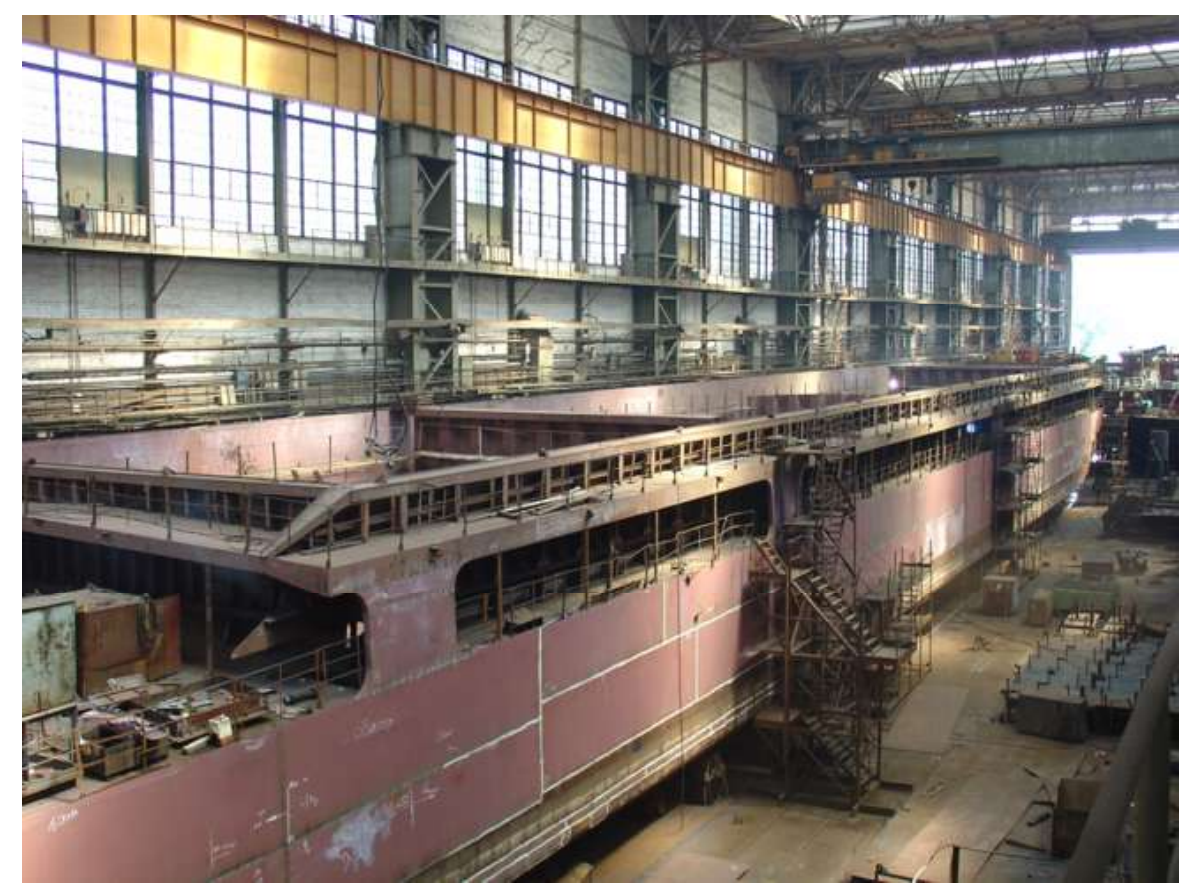

Puc. 13. Сухогрузное судно «Челси 3» проекта 005RSD06.01 в проиессе конверсии в 2005 году 
В 2006 году Геннадий Вячеславович создал службу поддержки борьбы за живучесть (Emergency Response Service) - ERS MEB. Служба ERS MEB имеет в своем распоряжении программное обеспечение, позволяющее производить расчеты аварийной остойчивости и остаточной прочности, оценивать возможный разлив нефти при столкновениях, посадках на мель, конструктивных разрушениях, пожарах, взрывах и др. подобных ситуациях, когда происходит аварийное изменение нагрузки и (или) несущей способности корпуса судна.

Помимо обслуживания танкеров 5000 тонн дедвейтом и более, Геннадий Вячеславович лично руководил (и успешно руководил) расчетной поддержкой большого количества аварийно-спасательных операций: массовая трагедия в Керченском проливе 11 ноября 2007 года с судами смешанного плавания из-за шторма, посадка на мель с водотечностью судна «Palmali Discovery» 3 июня 2010 года, катастрофа с «Булгарией» 11 июля 2011 года, уникальная судоподъемная операция по одновременному подъему затонувших плавдока №154 и танкера «Волгонефть-263» на Ильичевском СР3 8 сентября 2011 года, спасение танкера «Григорий Бугров» с 6138 тонн мазута на борту с затоплением машинного отделения 13 октября 2011 года, снятие с мели и обеспечение перехода железнодорожного парома «Феруз» после снятия с мели 8-9 февраля 2012 года, и многие-многие другие.

Самой яркой спасательной операцией можно назвать операцию по спасению и подъему на берег танкера-бункеровщика «Делфи» в августесентябре 2020 года, в которой Геннадий Вячеславович принимал непосредственное участие, обеспечивая расчетную инженерную поддержку по приглашению и просьбе Губанкова Юрия Петровича (президент «Бруклин-Киев») [36] (см. рисунок 14). За участие в операции был награжден почетным знаком Одесского городского главы «Благодарность».

Результатом активной научной деятельности стала защита докторской диссертации в 2005 году на тему «Методология обеспечения надежности и безопасности корпусов судов ограниченных районов плавания» [37] (см. рисунок 15).

В рамках исследования решались следующие задачи:

- анализ условий эксплуатации и систематизация внешних воздействий на корпуса судов смешанного плавания;

- разработка методов оценки риска нарушения надежности корпусов судов смешанного плавания с выявлением основных опасностей, требующих корректировки действующих нормативных требований к прочности и надежности корпусов, в том числе в ранее не рассматриваемых состояниях;

- разработка норм и методов расчета и контроля прочности корпусов судов смешанного плавания на стадии проектирования и при анализе 
ВІСНИК

ОДЕСЬКОГО НАЦІОНАЛЬНОГО

МОРСЬКОГО УНІВЕРСИТЕТУ
HERALD

OF THE ODESSA NATIONAL

MARITIME UNIVERSITY № 2 (65), 2021

фактических износов и деформаций, создании правил классификационных обществ;

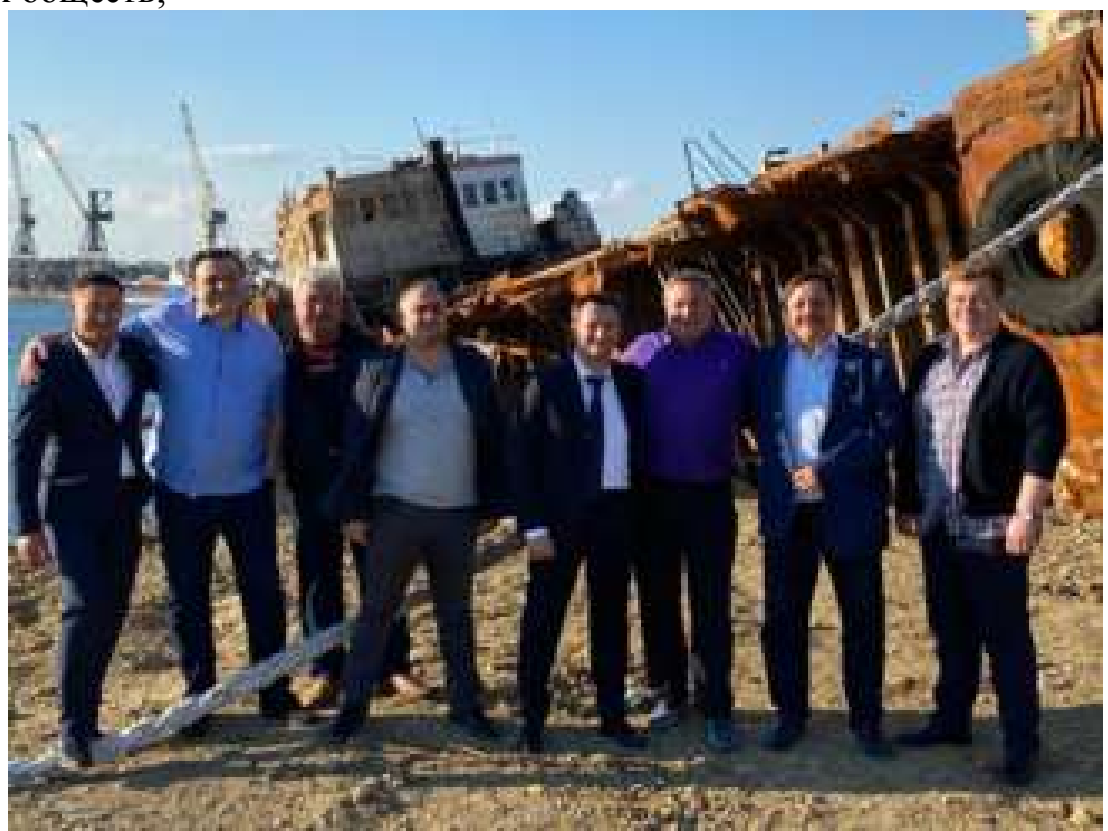

Рис. 14. Команда, спасавшая "Делфи», после завершения спасательной операчии

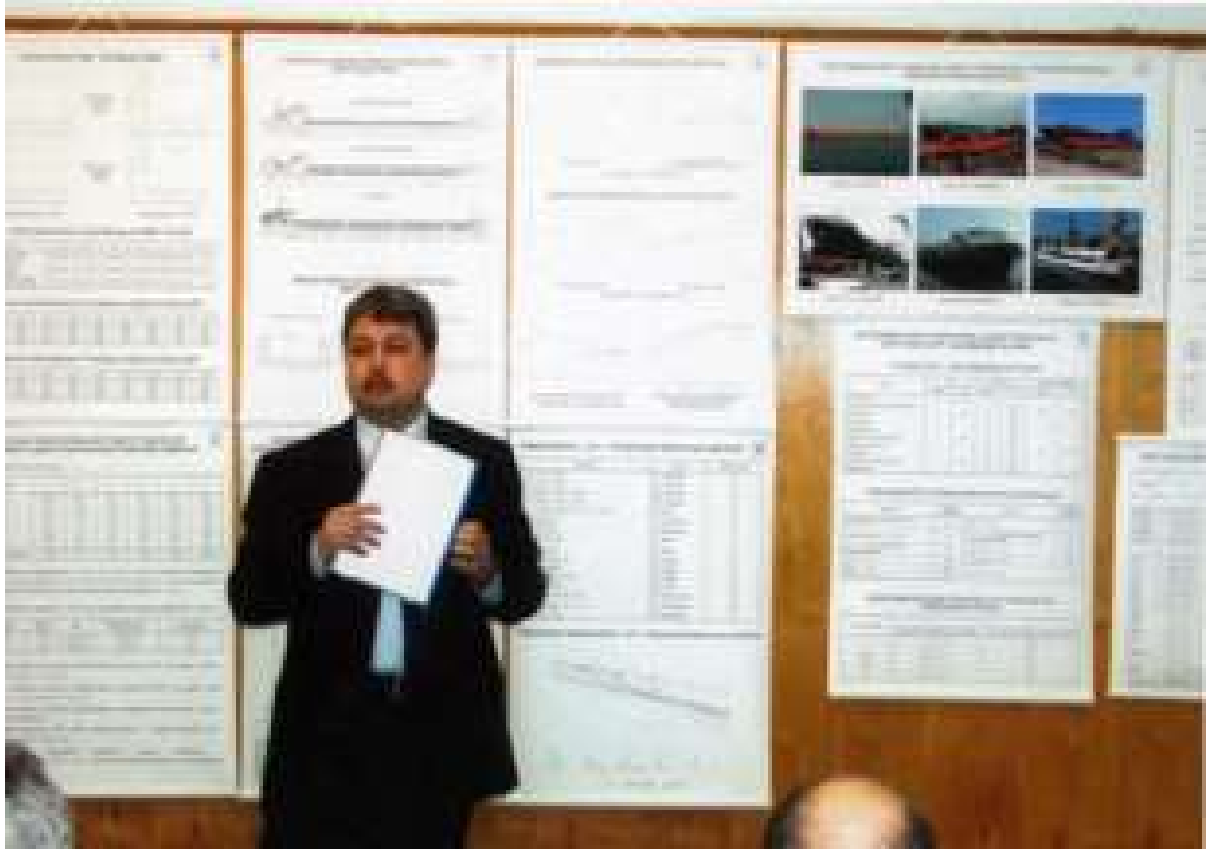


ВІСНИК

ОДЕСЬКОГО НАЦІОНАЛЬНОГО МОРСЬКОГО УНІВЕРСИТЕТУ
HERALD

OF THE ODESSA NATIONAL

MARITIME UNIVERSITY № 2 (65), 2021

Рис. 15. Егоров Геннадий Вячеславович на защите докторской диссертачии в Наџиональном университете кораблестроения в 2005 году - разработка современной методологии проектирования судов смешанного плавания, включая выбор главных характеристик;

- разработка методологии обоснования обновления, конверсии и модернизации судов как способов продления срока службы судов.

Практическое значение диссертации состояло во внедрении результатов диссертации в процесс проектирования Бюро судов смешанного и ограниченного района плавания нового поколения и создании разделов правил и нормативных документов РС, РСУ, РРР [37].

Являлся академиком Транспортной Академии Украины и академиком Академии Наук Судостроения Украины.

С 2008 года стал профессором кафедры теории и проектирования судов Национального университета кораблестроения.

В 2011 году стал Лауреатом государственной премии Украины за создание нового поколения универсальных транспортных судов и средств океанотехники [38] (см. рисунок 16).

С 2011 года работал в составе экспертного совета по машиноведению и машиностроению Высшей аттестационной комиссии Украины.

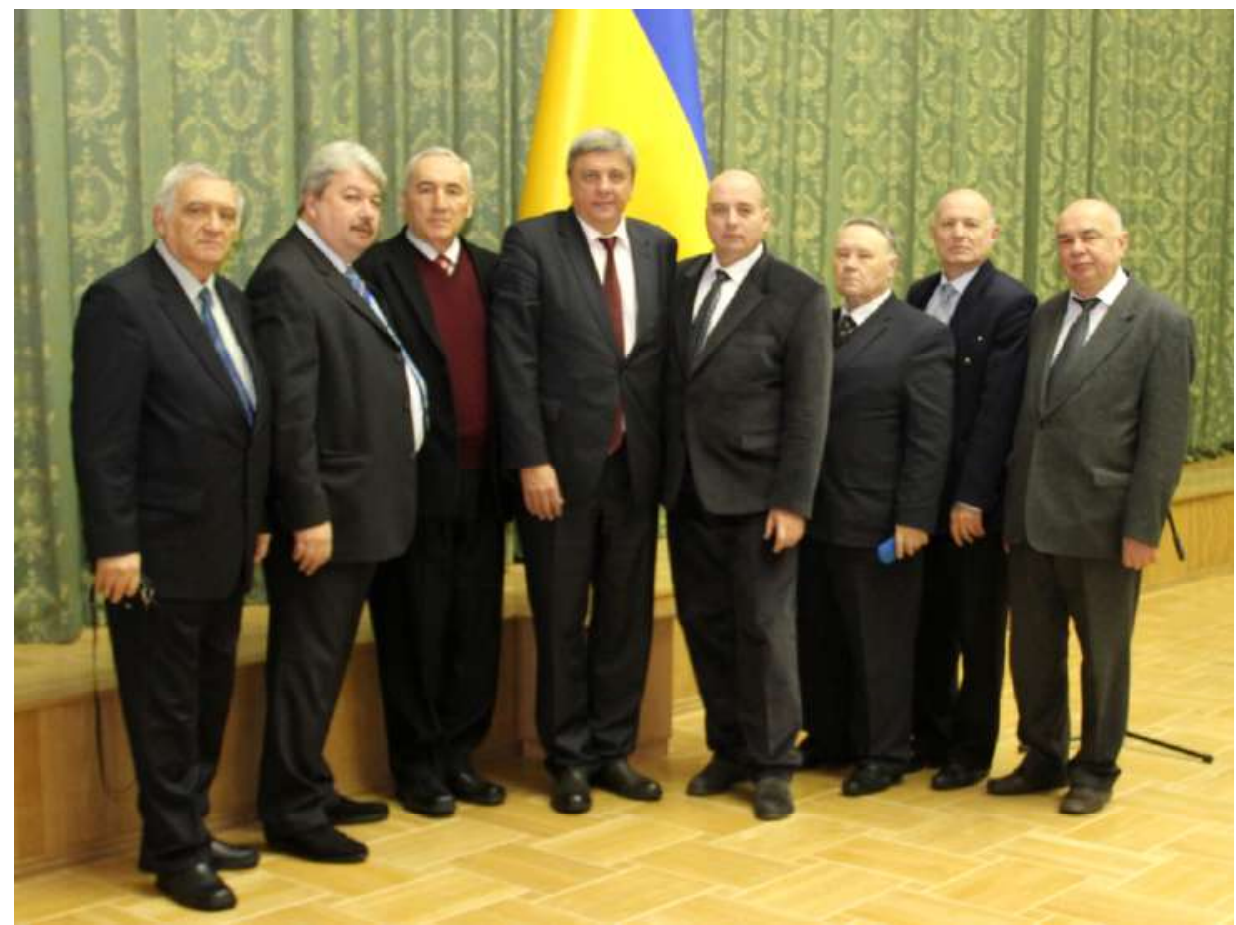


ВІСНИК

ОДЕСЬКОГО НАЦІОНАЛЬНОГО МОРСЬКОГО УНІВЕРСИТЕТУ № 2 (65), 2021
HERALD

OF THE ODESSA NATIONAL MARITIME UNIVERSITY № 2 (65), 2021

Рис. 16. Лауреаты государственной премии Украины 2011 года за создание нового поколения универсальных транспортных судов и средств океанотехники

Провел огромное количество лекций, уроков, вебинаров по актуальным вопросам судоходства и судостроения, как для профессиональной аудитории, так и для студентов (см. рисунок 17). В 2020 году был проведен даже один вебинар для школьников «Что нам стоит судно построить. Судно город в городе». Геннадий Вячеславович всегда очень трепетно относился к молодым кадрам. Большинство сотрудников Бюро начали свой трудовой путь, будучи студентами.

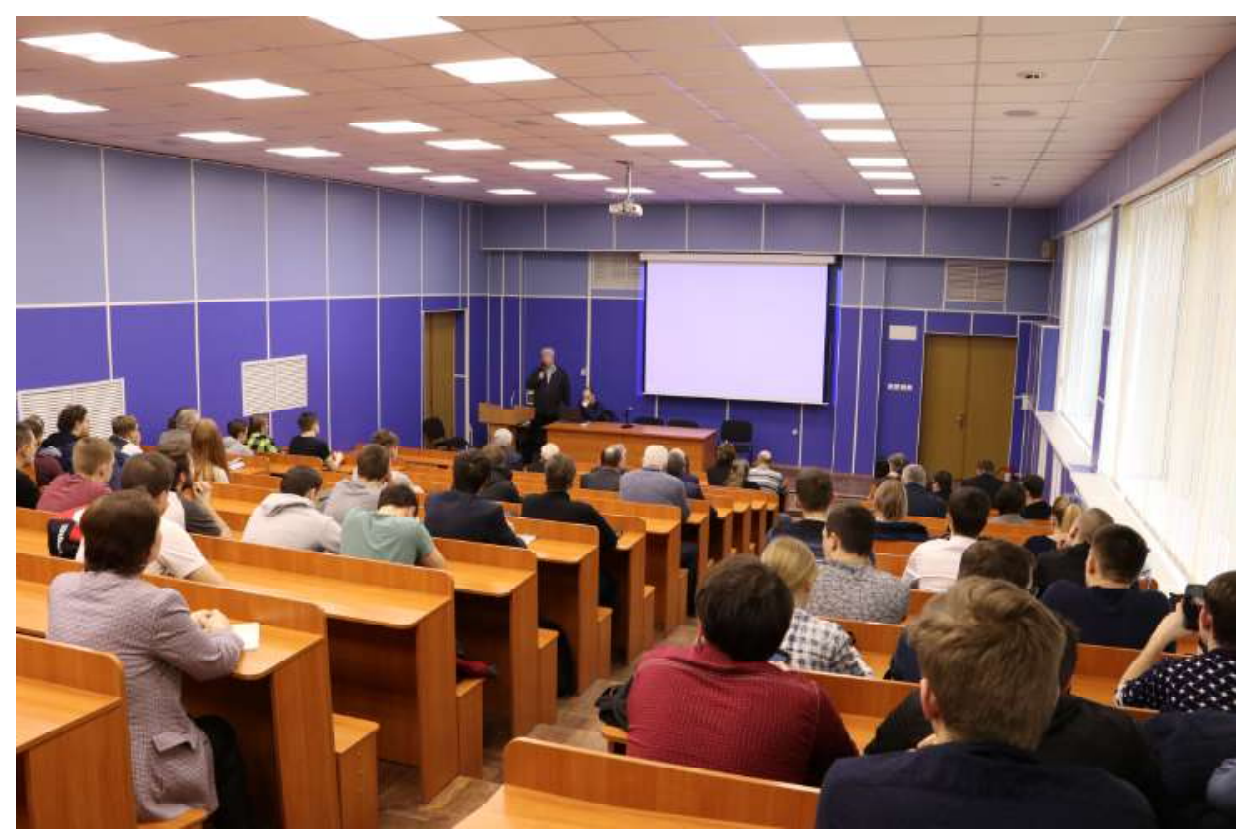

Рис. 17. Одна из открытых лекиий профессора Г.В. Егорова в Волжском государственном университете водного транспорта в Нижнем Новгороде, 2020 год

Параллельно с основной работой профессор Г.В. Егоров налаживал контакты с международными институтами и принимал активное участие в работах международных конференций и конгрессов. Основной результат такого общения - мировое признание и обмен информацией касаемо последних разработок в кораблестроении.

В 2009 году профессор Г.В. Егоров издал уникальную монографию «Либерти» - значит свобода». Книга посвящена истории проектирования в США и эксплуатации в СССР сухогрузных судов типа «Либерти» - самой массовой в мировой истории серии судов [39]. Мате- 
ВІСНИК

ОДЕСЬКОГО НАЦІОНАЛЬНОГО

МОРСЬКОГО УНІВЕРСИТЕТУ

№ 2 (65), 2021
HERALD

OF THE ODESSA NATIONAL

MARITIME UNIVERSITY № 2 (65), 2021

риалы для книги собирал лично, большую часть из которых удалось добыть во время командировок в США в 2000-2008 годах.

Геннадий Вячеславович был Почетным членом Британского Королевского Общества Корабельных Инженеров (FRINA) и Членом Американского Общества Кораблестроителей и Морских Инженеров (SNAME).

В рамках Международного Конгресса по конструкции корпусов судов и морских сооружений ISSC работал более 20 лет [40-45] (см. рисунок 18).

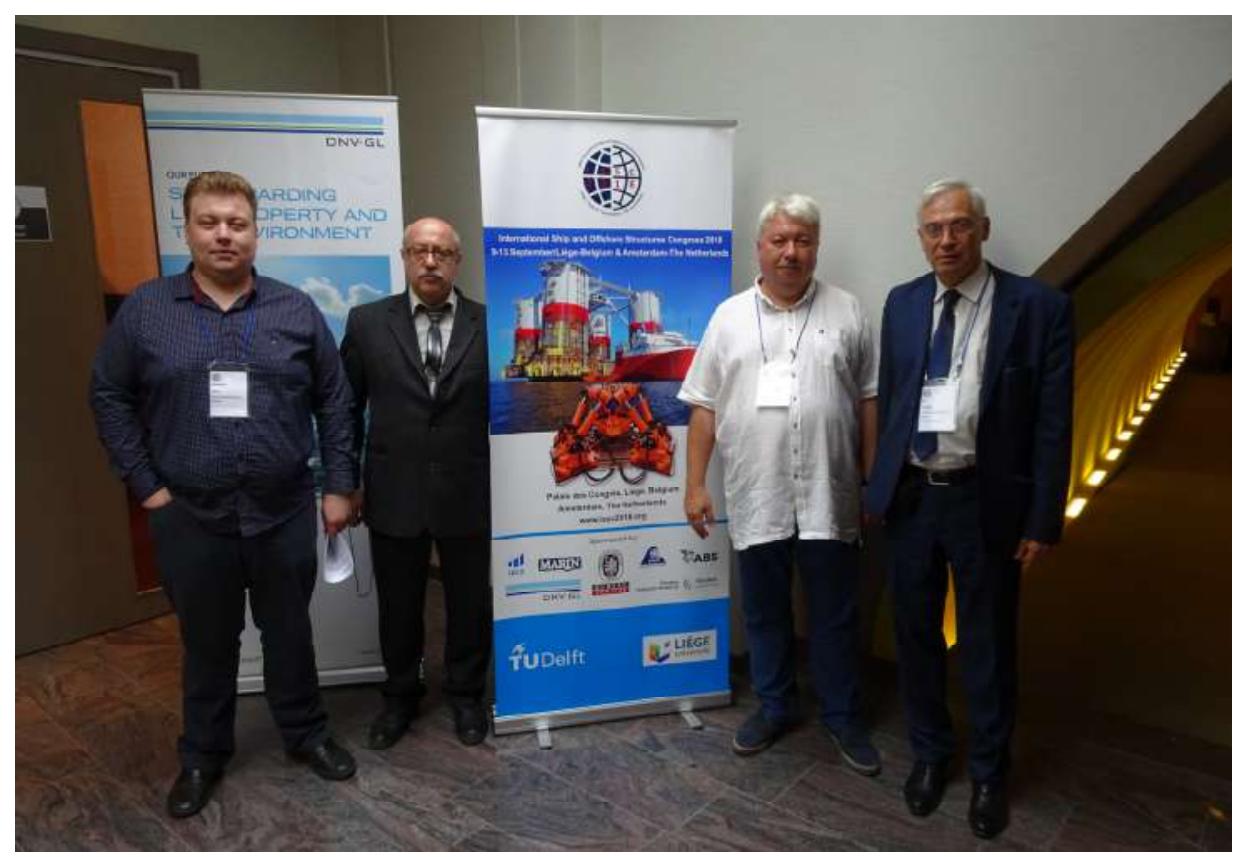

Рис. 18. Сотрудники Морского Инженерного Бюро

во главе с профессором Г.В. Егоровым на 20 Конгрессе ISSC в 2018 году

Профессор Геннадий Вячеславович развивался всегда. Казалось бы, достиг всех возможных высот, но нет... В последние два года своей жизни Геннадий Вячеславович поднялся на качественно иной уровень: высокопрофессиональные вебинары по теме проектирования, судостроения и судоходства, собиравшие сотни специалистов, актуальные статьи, инженерная поддержка в спасательной операции «Делфи».

Причем информацию к вебинарам готовил лично сам. К слову, в свою последнюю командировку в Иркутск Геннадий Вячеславович поехал с целью подготовки к новому вебинару, а также с целью инспекции уникального танкера-бункеровщика-эколога «Георгий Москалев» 
проекта RT37 Морского Инженерного Бюро, построенного в 2020 году для Байкала (см. рисунок 19).

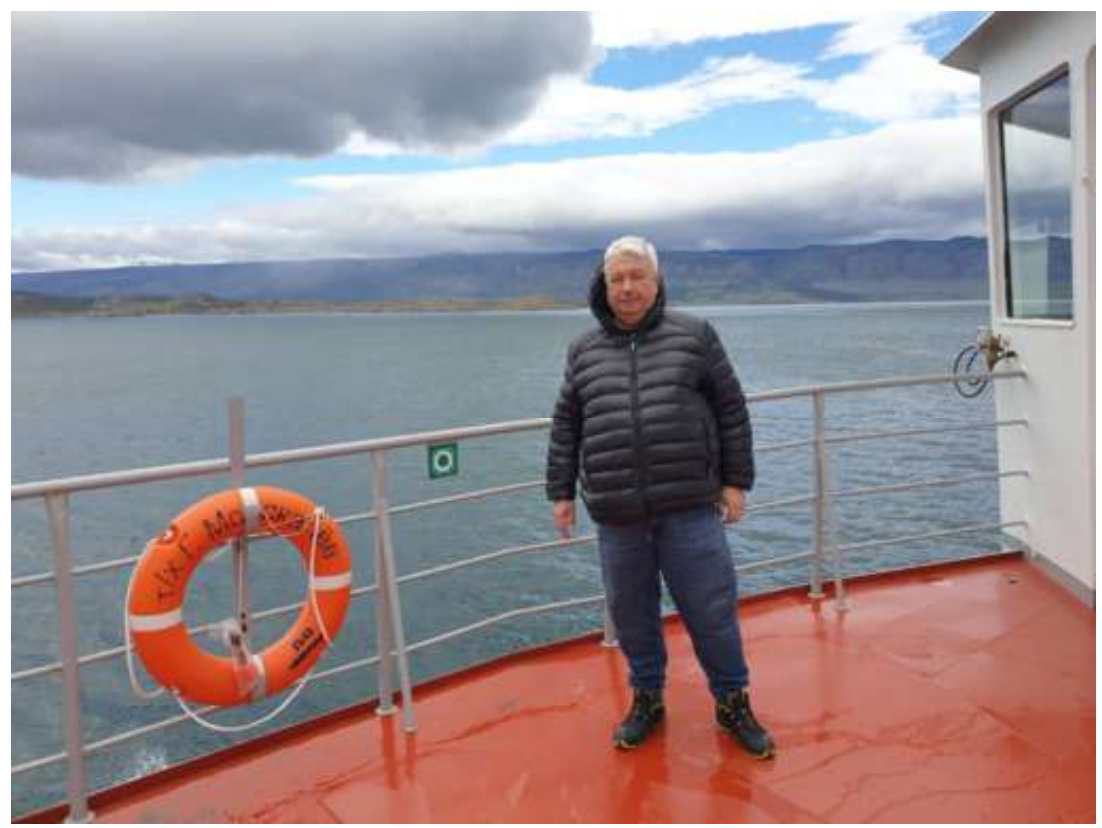

Рис. 19. Последнее фото профессора Г.В. Егорова.

На борту танкера-бункеровщика-эколога «Георгий Москалев» проекта RT37 29 мая 2021 года

Заключение. Судостроительные и судоходные отрасли потеряли легендарную личность. Замены нет и не будет. Ушел из жизни настоящий профессионал.

За 26 лет по проектам руководимого Геннадием Вячеславовичем Морского Инженерного Бюро было построено более 420 судов, огромное количество судов было модернизировано и переоборудовано. Написано более 1000 актуальных научных работ.

Под управлением профессора Г.В. Егорова, Бюро прошло путь от небольшой фирмы, занимающейся исключительно расчетными задачами по корпусу судна и научными исследованиями по заказу классификационных обществ, до организации, выполняющей практически весь спектр инжиниринговых работ для судоходства и судостроения.

07 июня 2021 года руководство судоходной компании «Идель» приняло решение назвать новое многоцелевое сухогрузное судно дедвейтом 8144 тонны проекта RSD59, заложенное 25 мая 2021 года на Окской судоверфи, именем Геннадия Егорова. Судно будет отвечать повышенным экологическим требованиям ИМО TIER III (DE-Tier III) по выбросам в атмосферу. 
Память о профессоре Геннадии Вячеславовиче Егорове вечна. Она во всех разработках и концептах Морского Инженерного Бюро.

\section{REFERENCE}

1. Egorov, G.V., Ilnitskiy, I.A., Yaroshenko, V.P. (2021). Innovatsionnyy kontsept gruzopassazhirskogo sudna dlya Dal'nego Vostoka $s$ arkticheskim ledovym klassom [Innovative concept of a cargopassenger vessel for the Far East with Arctic ice class]. Sudostroenie (Shipbuilding), 2, 13-24 [in Russian].

2. Egorov, G.V. (1993). Razrabotka metodov optimizatsii prochnostnykh resheniy pri ekspluatatsii sudov [Development of methods for optimization of strength solutions during the operation of ships]. PhD dissertation, Odessa, OIIMF, 431 p. [in Russian].

3. Website of Marine Engineering Bureau [Electronic source]. URL: http://meb.com.ua/news/news.html? 1375 (access date 06.08.2021).

4. Egorov, G.V. (2001). Modernizatsiya kak sposob prodleniya sroka sluzhby $i$ obespecheniya bezopasnoy ekspluatatsii sushchestvuyushchikh sudov [Modernization as a way to extend the service life and ensure the safe operation of existing ships]. Vestnik OGMU (Reporter of Odessa State Maritime University), 6, 4661 [in Russian].

5. Egorov, G.V. (2000). Metodicheskiye ukazaniya po razrabotke instruktsiy po zagruzke, bukletov po perevozke nezernovykh navalochnykh gruzov i priborov kontrolya zagruzki morskikh sudov [Methodological guidelines for the development of loading instructions, booklets for the carriage of non-grain bulk cargo and devices for monitoring the loading of sea-going vessels]. Russian Maritime Register of Shipping. Collection of normative and methodological materials. Book nine, St. Petersburg, $35 \mathrm{p}$. [in Russian].

6. Egorov, G.V. (2001). Pravila klassifikatsii $i$ postroyki sudov vnutrennego plavaniya (dlya Dunayskogo basseyna) [Rules for the Classification and Construction of Inland Navigation Vessels (for the Danube Basin)]. Russian Maritime Register of Shipping, St. Petersburg, 404 p. [in Russian].

7. Egorov, G.V. (2003). Tanker smeshannogo reka-more plavaniya dedveitom 6440 tonn "Armada Lider» s vinto-rulevymi kolonkami [6440 dwt river-sea tanker "Armada Leader» with rudderpropeller complex]. Vestnik ONMU (Reporter of Odessa National Maritime University), 12, 3-19 [in Russian].

8. Egorov, G.V. (2008). Proektirovanie i postroyka koasterov i sudov smeshannogo plavaniya [Design and building of coasters and riv- 
er-sea vessels]. Sudostroenie i sudoremont (Shipbuilding and ship repair), Odessa, 128 p. [in Russian].

9. Egorov, G.V. (2007). Proektirovanie sudov ogranichennykh rayonov plavaniya na osnovanii teorii riska [Design of restricted area vessels based on risk theory]. Sudostroenie (Shipbuilding), St. Petersburg, 384 p. [in Russian].

10. Egorov, G.V. (2010). Razrabotka «lineyki» sovremennykh proektov morskikh sukhogruznykh sudov dedveitom okolo 10 tys. tonn $i$ menee [Development of «lineup» of modern projects of sea drycargo vessels with deadweight about 10000 tons and less]. Collection book of Int. Sc.-Prac. Conf. in honour of 80 years of prof. V.V. Kozlyakov, Sudostroenie i sudoremont, Odessa, 39-48 [in Russian].

11. Egorov, G.V. (2011). Obnovlennaya lineyka mnogotselevykh sukhogruznykh sudov smeshannogo plavaniya $i$ koasterov Morskogo Inzhenernogo Byuro [Updated lineup of multipurpose river-sea dry-cargo vessels and coasters of Marine Engineering Bureau]. Morskaya Birzha (Maritime Market), 3 (37), 38-42 [in Russian].

12. Egorov, G.V., Tonyuk, V.I. (2013). Tanker smeshannogo rekamore plavaniya dedveitom $v$ reke/more 5427/7030 tonn pr. RST27 tipa «VF Tanker» $s$ ekstremalno polnymi obvodami [Riversea tanker with river/sea deadweight of 5427/7030 tons pr. RST27 of «VF Tanker» type with extremely fat hull contours]. Sudostroenie i sudoremont, Odessa, 57-58, 22-35 [in Russian].

13. Egorov, G.V. (2014). Proektnyi ryad neftenalivnykh sudov smeshannogo reka-more plavaniya [Parametrical lineup of river-sea tankers]. Vestnik ONMU (Reporter of Odessa National Maritime University), 2 (41), 5-22 [in Russian].

14. Egorov, G.V., Tonyuk, V.I. (2019). Seriya tankerov-produktovozovkhimovozov klassa "Volgo-Don maks» so «sverkhpolnymi» obvodami pr. RST27M dedveitom v more/reke 7900/5360 tonn [The series of product and chemical tankers of «Volgo-Don maks» class with "superfull» hull contours of RST27M project with deadweight at sea/river 7900/5360 tons]. Sudostroenie (Shipbuilding), St. Petersburg, 2, 18-24 [in Russian].

15. Egorov, G.V. (2018). «Sverkhpolnye» mnogotselevye sukhogruznie suda «Volgo-Don max» klassa proekta RSD59 tipa «Pola Makariya» [«Superfull» multipurpose dry-cargo vessels of «Volgo-Don max» class of RSD59 project of «Pola Makariya» type]. Morskoy Vestnik (Maritime Reporter), 4 (68), 17-27 [in Russian]. 
16. Egorov, G.V., Egorov, A.G. (2018). Osnovnye resheniya novogo pokoleniya «sverkhpolnykh» gruzovykh sudov smeshannogo rekamore $i$ vnutrennego plavaniya [Main decisions of new generation «superfull» river and river-sea cargo vessels]. Sudostroenie (Shipbuilding), St. Petersburg, 4, 18-24 [in Russian].

17. Egorov, G.V., Avtutov, N.V., Chernikov, D.V. (2017). "Lineyka» sluzhebno-vspomogatelnykh $i$ tehnicheskikh sudov novogo pokoleniya [Lineup of service-auxiliary and technical vessels of new generation]. Vestnik ONMU (Reporter of Odessa National Maritime University), 1 (50), 26-54 [in Russian].

18. Egorov, G.V., Ilnytskyi, I.A., Tonyuk, V.I., Avtutov, N.V., Chernikov, D.V. (2019). Lineyka mnogofunktsionalnykh spasatelnykh sudov Morskogo Inzhenernogo Buro: opyt proektirovaniya, postroyki i ekspluatatsii [Lineup of multifunctional salvage vessels of Marine Engineering Bureau: design, construction and operation experience]. Proceedings of BMS Sc.-Tech. Conf. in honour of Prof., Dr. O.M. Paliy, Krylov State Research Center, St. Petersburg, 111-112 [in Russian].

19. Egorov, G.V. (2015). Obosnovaniye «lineyki» mnogofunktsional'nykh avariyno-spasatel'nykh sudov dlya raboty $v$ pribrezhnykh moryakh Rossii [Justification of the «lineup» of multifunctional rescue vessels for work in the coastal seas of Russia]. Marine innovative technologies: Proceedings of the Admiral G.I. Nevelskoy, 3 (29), Volume 1, 28-44 [in Russian].

20. Egorov, G.V., Avtutov, N.V., Chernikov, D.V. (2016). Novyye suda $i$ paromy dlya obespecheniya lineynykh perevozok passazhirov po vodnym kommunikatsiyam [New ships and ferries for providing linear transportation of passengers on water communications]. Vestnik ONMU (Reporter of Odessa National Maritime University), 3 (49), 45-69 [in Russian]

21. Egorov, G.V. (2016). O novoy kontseptsii razvitiya passazhirskogo sudostroyeniya [About new concept for the development of passenger shipbuilding]. Rivers of Russia. National Tourism Forum, Collection of materials, Zavidovo, 110-120 [in Russian].

22. Egorov, G.V. (2014). "Lineyka» gruzovykh i gruzopassazhirskikh paromov dlya Chernogo morya ["Lineup» of cargo and cargopassenger ferries for the Black Sea]. Morskaya Birzha (Maritime Market), 1 (47), 14-27 [in Russian].

23. Egorov, A.G., Chernikov, D.V. (2020). Analiz i perspektivy rossiyskikh paromnykh liniy Baltiyskogo morya [Analysis and prospects of Russian ferry lines in the Baltic Sea]. Proceedings of 
Krylov State Research Center, St. Petersburg, Special Volume 2, 187-192 [in Russian].

24. Egorov, G.V., Anisimov, K.O. (2020). Analiz i perspektivy mezhdunarodnykh zheleznodorozhnykh $i$ avtomobil'nykh paromnykh liniy Kaspiyskogo basseyna [Analysis and prospects of international rail and road ferry lines of the Caspian basin]. Proceedings of Krylov State Research Center, St. Petersburg, Special Volume 2, 199-204 [in Russian].

25. Ilnytskyi, I.A., Tonyuk, V.I. (2020). Analiz i perspektivy paromnykh $i$ gruzopassazhirskikh soobshcheniy na rossiyskom Dal'nem Vostoke [Analysis and prospects of ferry and cargo-passenger services in the Russian Far East]. Proceedings of Krylov State Research Center, St.Petersburg, Special Volume 2, 205-211 [in Russian].

26. Efremov, N.A., Egorov, G.V. (2007). Kak v usloviyakh ogranichennykh resursov sokhranit' otechestvennyy flot [How to save the domestic fleet in conditions of limited resources]. Journal RT, Moscow, 32 p. [in Russian].

27. Efremov, N.A., Egorov, G.V. (2005). Opyt stroitel'stva sudov s ispol'zovaniyem elementov ekspluatirovavshegosya flota [Experience in building ships using elements of the operating fleet]. River transport, 25 p. [in Russian].

28. Sevryukov, V.V., Avtutov, N.V., Belega,O.V., Bilokurets, A.A., Egorov, G.V., Ilnytskyi, I.A., Makhek, I.I., Onishchenko, I.V., Solov'yev, A.A. (2006). Pravila po stroitel'stvu morskikh sudov s ispol'zovaniyem elementov ekspluatirovavshikhsya sudov-donorov [Rules for the Construction of Sea-Going Ships Using Elements of Operated Donor Vessels], Kiev: Shipping Register of Ukraine, 45 p. [in Russian].

29. Egorov, G.V., Avtutov, N.V. (2007). Sozdaniye chernomorskikh zheleznodorozhnykh paromov s primeneniyem elementov sushchestvuyushchikh sudov [Creation of Black Sea railway ferries using elements of existing ships]. Vestnik ONMU (Reporter of Odessa National Maritime University), 23, 52-67 [in Russian].

30. Egorov, G.V., Avtutov, N.V. (2007). Obshchiye podkhody $k$ stroi-tel'stvu sudov s ispol'zovaniyem elementov sudov-donorov [General approaches to the construction of ships using elements of donor ships]. Collection book of National University of Shipbuilding, 5, 17-24 [in Russian]. 
31. Egorov, G.V., Avtutov, N.V. (2009). Sukhogruznyye suda smeshannogo plavaniya serii "Chelsi», postroyennyye s ispol'zovaniyem elementov sudov-donorov [Chelsea series river-sea dry-cargo vessels, built using elements of donor vessels]. Vestnik ONMU (Reporter of Odessa National Maritime University), 26, 5-18 [in Russian].

32. Egorov, G.V., Efremov, N.A. (2011). Chto takoye "konversiya» sudov? [What is vessel "conversion»?]. Morskaya Birzha (Maritime Market), 2 (36), 18-27 [in Russian].

33. Anisimov, K.O., Egorov, G.V., Efremov, N.A., (2012). Stroitel'stvo novykh sudov $s$ ispol'zovaniyem elementov sudov-donorov real'nyy put' sokhraneniya rossiyskikh rechnykh kruizov [Construction of new vessels using elements of donor vessels is a real way to save Russian river cruises]. River transport (XXI century), 4, 51-62 [in Russian].

34. Egorov, G.V., Avtutov, N.V. (2016). Proyektirovaniye tankerovkhimovozov-vinovozov s primeneniyem elementov sudov-donorov [Design of chemical tankers-vine carrier vessels using elements of donor vessels]. Collection book of All-Ukrainian scientific and technical. conf. with int. part. "Modern technologies for the design, construction, operation and repair of ships, marine technical equipment and engineering structures», Nikolayev, National University of Shipbuilding, 4-6 [in Russian].

35. Egorov, G.V., Egorov, A.G. (2019). Analiz zakonomer- nostey spisaniya rechnykh kruiznykh sudov i prognoz sostava rechnogo flota s opredeleniyem naiboleye vostrebovannykh tipov sudov dlya konversii i modernizatsii [Analysis of the regularities of the write-off of river cruise ships and the forecast of the composition of the river fleet with the determination of the most popular types of ships for conversion and moderni-zation]. Morskoy Vestnik (Maritime Reporter), 1 (69), 21-27 [in Russian].

36. Gubankov, Yu.P., Ivanov, A.I., Golodnitskyi, A.G., Egorov, G.V. (2020). Spasayem «Delfi» - unikal'naya operatsiya [Saving «Delfi»-a unique operation]. Sudohodstvo (Shipping), 10 (189), 8-23 [in Russian].

37. Egorov, G.V. (2004). Metodologiya obespecheniya nadezhnosti $i$ bezopasnosti korpusov sudov ogranichennykh rayonov plavaniya [Methodology for ensuring the reliability and safety of the hulls of ships in limited navigation areas]. Doctoral dissertation, Nikolayev, National University of Shipbuilding, 477 p. [in Russian]. 
38. Ryzhkov, S.S., Blintsov, V.S., Egorov, G.V., Zhukov, Yu.D., Kvasnitskyi, V.F., Koshkin, K.V., Krivtsun, I.V., Nekrasov, V.A., Sevryukov, V.V., Solonichenko, Yu.V. (2011). Stvorennya universal'nykh transportnykh suden ta zasobiv okeanotekhniky: monohrafiya [Creation of universal transport vessels and means of ocean engineering], Nikolayev, National University of Shipbuilding, 340 p. [in Ukrainian].

39. Egorov, G.V. (2009). "Liberti» - znachit svoboda ["Liberty» means freedom]. Odessa, Nickolay Dubrov publishing house, 196 p. [in Russian].

40. Bruce, G., Duan, M., Egorov, G.V., Folso, R., Fujimoto, Garbatov, Y.Y., Hire, J-C.Le, Shin, B.-C., Vardal, O.T. (2003). Inspection and Monitoring. Report of Specialist Committee V.2 // Proc. of 15th ISSC-2003, San Diego (USA), Vol. 2, 37-69.

41. Cho, K-N, Arai, M., Basu, R.P., Besse, R., Birmingham, H., Boonstra, Y-Q, Chen, G., Egorov, J. Hampshire, C-F. Hung, B. Leira, W. Moore, V. Zanic. (2006). Design Principles and Criteria. Report of Committee IV.1 // Proc. of $16^{\text {th }}$ ISSC-2006. Southampton (UK), Vol. 1, 521-599.

42. Soares, C.G., Basu R., Cerup Simonsen, B., Egorov, G.V., Hung, C.F., Lindstrom, P., Samuelides, E., Vredeveldt, A., Yoshikawa, T. (2009). Damage Assessment after accidental events. Report of Committee V.1 // Proc. of $17^{\text {th }}$ ISSC. 2009. Seoul (Korea), Vol. 2, 1-72.

43. Edzard Brunner, Richard W. Birmingham, Eirik Byklum, Yiugqiu Chen, Yuk F. Cheng, Jyotisman Dasgupta, Gennadiy Egorov, Jeppe Juhl, Byeoung S. Kang, Dale Karr, Yasumi Kawamura, Alan Klanac, Sean O'Neil, Enrico Rizzuto, Angelo Teixeira, Koichi Yoshida. (2012). Design Principles and Criteria. Report of Committee IV.1 // Proc. of $18^{\text {th }}$ ISSC. 2012. Rostock (Germany), Vol. 1, 435-506.

44. E. Rizzuto, J. Downes, M. Radon, G. Egorov, Y. Kawamura, S. O'Neil, R. Skjong, A. Teixeira. (2015). Design Principles and Criteria. Report of Committee IV.1 // Proc. of 19 $9^{\text {th }}$ ISSC. 2015. Cascais (Portugal), Vol. 1, 415-458.

45. M. Collette, Z. Zhan, L. Zhu, V. Zanic, T. Okada, T. Arima, R. Skjong, H.K. Jeong, G. Egorov. (2018). Design Principles and Criteria. Report of Committee IV.1 // Proc. of 20 ${ }^{\text {th }}$ ISSC. 2018. Liege (Belgium) \& Amsterdam (The Netherlands), Vol. 1 (Edited by M.L. Kaminski and P. Rigo), 549-607. 


\section{ЛИТЕРАТУРА}

1. Егоров, Г.В., Ильницкий, И.А., Ярошенко, В.П. Инновачионный конщепт грузопассажирского судна для Дальнего Востока с арктическим ледовым классом // Судостроение. 2021. № 2. C. 13-24.

2. Егоров, Г.В. Разработка методов оптимизации прочностных решений при эксплуатаџии судов: Дисс. на соиск. уч. ст. канд. техн. наук. Одесса: ОИИМФ, 1993. 431 с.

3. Сайт Морского Инженерного Бюро [Электронный ресурс]. URL: http://meb.com.ua/news/news.html? 1375 (дата обращения 06.08.2021).

4. Егоров, Г.В. Модернизачия как способ продления срока службы и обеспечения безопасной эксплуатаиии существующих судов // Вестник ОГМУ. Одесса: ОГМУ, 2001. Вып. 6. C. 46-61.

5. Егоров Г.В. Методические указания по разработке инструкиий по загрузке, буклетов по перевозке незерновых навалочных грузов и приборов контроля загрузки морских судов. Российский Морской Регистр Судоходства. Сб. нормативнометодических материалов. Кн. 9. СПб., 2000. 35 с.

6. Егоров, Г.В. Правила классификаџии и постройки судов внутреннего плавания (для Дунайского бассейна). Российский Морской Регистр Судоходства. СПб., 2001. 404 c.

7. Егоров, Г.В. Танкер смешанного река-море плавания дедвейтом 6440 тонн «Армада Лидер» с винто-рулевыми колонками // Вестник ОНМУ. Одесса: ОНМУ, 2003. Bып. 12. C. 3-19.

8. Егоров, Г.В. Проектирование и постройка коастеров и судов смешанного плавания // Одесса: Судостроение и судоремонт, 2008. $128 \mathrm{c}$.

9. Егоров, Г.В. Проектирование судов ограниченных районов плавания на основании теории риска. СПб.: Судостроение, 2007. $384 \mathrm{c}$.

10. Егоров, Г.В. Разработка «линейки» современных проектов морских сухогрузных судов дедвейтом около 10 тыс. тонн и менее / Сборник докладов междун. научно-практ. конф. в честь 80-летнего юбилея профессора В.В. Козлякова // Одесса: Судостроение и судоремонт, 2010. C. 39-48.

11. Егоров, Г.В. Обновленная линейка многоиелевых сухогрузных судов смешанного плавания и коастеров Морского Инженерного Бюро // Морская Биржа. 2011.№ 3 (37). С. 38-42. 
ВІСНИК

ОДЕСЬКОГО НАЦІОНАЛЬНОГО

МОРСЬКОГО УНІВЕРСИТЕТУ

№ 2 (65), 2021
HERALD

OF THE ODESSA NATIONAL

MARITIME UNIVERSITY № 2 (65), 2021

12. Егоров, Г.В., $\quad$ Тонюк, В.И. Танкер смешанного река-море плавания дедвейтом в реке/море 5427/7030 тонн пр. RST27 типа «ВФ танкер» с экстремально полньми обводами // Судостроение и судоремонт. 2013. № 57-58. С. 22-35.

13. Егоров Г.В. Проектный ряд нефтеналивных судов смеманного река-море плавания // Вестник ОНМУ. Одесса: ОНМУ, 2014. Bbin. 2 (41). C. 5-22.

14. Егоров, Г.В., $\quad$ Тонюк, В.И. Серия танкеров-продуктовозовхимовозов класса «Волго-Дон макс» со «сверхполнылим» обводами пр. RST27M дедвейтом в море/реке 7900/5360 тонн // Судостроение. 2019. № 2. С. 18-24.

15. Егоров, Г.В., Тонюк, В.И. «Сверхполные» многочелевые сухогрузные суда «Волго-Дон макс» класса проекта RSD59 типа «Пола Макария» // Морской Вестник. 2018. № 4 (68). C. 17-27.

16. Егоров, Г.В., Егоров, А.Г. Основные решения нового поколения «сверхполныху грузовых судов смешанного река-море и внутреннего плавания // Судостроение. 2018. № 4. С. 18-24.

17. Егоров, Г.В., Автутов, Н.В., Черников, Д.В. «Линейка» служебно-вспомогательных и технических судов нового поколения // Вестник ОНМУ. Одесса: ОНМУ, 2017. Bыn. 1 (50). C. 26-54.

18. Егоров, Г.В., Ильницкий, И.А., $\quad$ Тонюк, В.И., Автутов, Н.В., Черников, Д.В. Линейка многофункииональных спасательных судов Морского Инженерного Бюро: опыт проектирования, постройки и эксплуатацчи // Труды НТК по СМК, посвященной памяти д.т.н., проф. О.М. Палия. СПб.: Крыловский государственный научный центр, 2019. С. 111-112.

19. Егоров, Г.В. Обоснование «линейки» многофункциональньх аварийно-спасательных судов для работы в прибрежных морях России // Морские инновационные технологии: Трудыл Морского государственного университета имени адмирала Г.И. Невельского. 2015. Вып. № 3 (29). Том 1. C. 28-44.

20. Егоров, Г.В., Ильницкий, И.А., Егоров, А.Г. Новые суда и паромы для обеспечения линейных перевозок пассажиров по водным коммуникациям // Вестник OНМУ. Одесса: OHМУ, 2016. Bbın. 3 (49). C. 45-69.

21. Егоров, Г.В. $О$ новой концепцчи развития пассажирского судостроения // Реки России. Национальный туристский форум. Сб. материалов. Завидово. 2016. С. 110-120. 
ВІСНИК

ОДЕСЬКОГО НАЦІОНАЛЬНОГО

МОРСЬКОГО УНІВЕРСИТЕТУ

№ 2 (65), 2021
HERALD

OF THE ODESSA NATIONAL

MARITIME UNIVERSITY

22. Егоров, Г.В. «Линейка» грузовых $и$ грузопассажирских паромов для Черного моря // Морская Биржа. 2014.№ 1 (47). C. 14-27.

23. Егоров, А.Г., Черников, Д.В. Анализ и перспективы российских паромных линий Балтийского моря // Труды Крыловского государственного научного иентра. 2020. Спец. вып. № 2. C. 187-192.

24. Егоров, Г.В., Анисимов, К.О. Анализ и перспективы международных железнодорожных и автомобильных паромных линий Каспийского бассейна // Труды Крыловского государственного научного центра. 2020. Спец. вып. № 2. C. 199-204.

25. Ильницкий, И.А., Тонюк, В.И. Анализ и перспективы паромных и грузопассажирских сообщений на российском Дальнем Востоке // Труды Крыловского государственного научного иентра. 2020. Cnеu. вbin. № 2. C. 205-211.

26. Ефремов, Н.А., Егоров, Г.В. Как в условиях ограниченныхх ресурсов сохранить отечественный флот. М.: Журнал РТ, 2007. $32 \mathrm{c}$.

27. Ефремов, Н.А., Егоров, Г.В. Опыт строительства судов с использованием элементов эксплуатировавшегося флота // Речной транспорт. 2005. $25 \mathrm{c}$.

28. Севрюков, В.В., Автутов, Н.В., Белега, О.В., Билокуреи, А.А., Егоров, Г.В., Ильничкий, И.А., Махек, И.И., Онищенко, И.В., Соловьев, А.А. Правила по строительству морских судов с использованием элементов эксплуатировавщихся судовдоноров / Под ред. Севрюкова В.В. К.: РУ, 2006. 45 с.

29. Егоров, Г.В., Автутов, Н.В. Создание черноморских железнодорожных паромов с применением элементов существующих судов // Вестник ОНМУ. Одесса: ОНМУ, 2007. Bып. 23. C. 52-67.

30. Егоров, Г.В., Автутов, Н.В. Общие подходы к строительству судов с использованием элементов судов-доноров // Сб. науч. трудов НУК. Николаев: НУК, 2007. № 5. С. 17-24.

31. Егоров, Г.В., Автутов, Н.В. Сухогрузные суда смешанного плавания серии "Челси», построенные с использованием элементов судов-доноров // Вестник ОНМУ. Одесса: ОНМУ, 2009. Buin. 26. C. 5-18.

32. Егоров, Г.В., Ефремов, Н.А. Что такое «конверсия» судов? // Морская Биржа. 2011. № 2 (36). С. 18-27.

33. Анисимов, К.О., Егоров, Г.В., Ефремов, Н.А. Строительство новых судов с использованием элементов судов-доноров - реальный путь сохранения российских речных круизов // Речной транспорт (ХХІ век). 2012. № 4. C. 51-62. 
34. Егоров, Г.В., Автутов, Н.В. Проектирование танкеров-химовозов-виновозов с применением элементов судов-доноров // Материаль Всеукраинской научно-техн. конф. с межд. уч. «Современные технологии проектирования, строительства, эксплуатации и ремонта судов, морских технических средств и инженерных сооружений». Николаев: НУК, 2016. С. 4-6.

35. Егоров Г.В., Егоров А.Г. Анализ закономерностей списания речных круизных судов и прогноз состава речного флота c определением наиболее востребованных типов судов для конверсии и модернизациии // Морской Вестник. 2019. № 1 (69). С. 21-27.

36. Губанков, Ю.П., Иванов, А.И., Голодницкий, А.Г., Егоров, Г.В. Спасаем «Delfi» - уникальная операция // Журнал «Судоходство», 2020. № 10 (189). C. 8-23.

37. Егоров Г.В. Методология обеспечения надежности и безопасности корпусов судов ограниченных районов плавания: Дисс. на соиск. уч. ст. докт. техн. наук. Николаев, НУК, 2004. $477 \mathrm{c}$.

38. Рижков, С.С., Блінцов, В.С., Сгоров, Г.В., Жуков, Ю.Д., Кваснищький, В.Ф., Кошкін, К.В., Крівиун, І.В., Некрасов, В.О., Севрюков, В.В., Солоніченко, Н.В. / 3 а ред. С.С. Рижкова. Створення універсальних транспортних суден та засобів океанотехніки: монографія. Миколаїв: Видавництво НУК, 2011. 340 с.

39. Егоров Г.В. «Либерти»-значит свобода. Одесса: Издатель Николай Дубров, 2009. 196 с.

40. Bruce, G., Duan, M., Egorov, G.V., Folso, R., Fujimoto, Y. Garbatov, Hire, J-C.Le, Shin, B.-C., Vardal, O.T. Inspection and Monitoring. Report of Specialist Committee V.2 // Proc. of $15^{\text {th }}$ ISSC. 2003. San Diego (USA). 2003. Vol. 2. P. 37-69.

41. Cho, K-N, Arai, M., Basu, R., Besse, P., Birmingham, R., Boonstra, H., Chen, Y-Q., Egorov, G. Hampshire, G., Hung, C-F., Leira, B., Moore, W., Zanic. V. Design Principles and Criteria. Report of Committee IV.1 // Proc. of $16^{\text {th }}$ ISSC-2006. Southampton (UK), 2006. Vol. 1. P. 521-599.

42. Soares, C.G., $\quad$ Basu, R., Cerup Simonsen, B., Egorov, G.V., Hung, C.F., Lindstrom, P., Samuelides, E., Vredeveldt, A., Yoshikawa, T. Damage Assessment after accidental events. Report of Committee V.1 // Proc. of $17^{\text {th }}$ ISSC. 2009. Seoul (Korea), 2009. Vol. 2. P. 1-72. 
43. Edzard Brunner, Richard W. Birmingham, Eirik Byklum, Yiugqiu Chen, Yuk F. Cheng, Jyotisman Dasgupta, Gennadiy Egorov, Jeppe Juhl, Byeoung S. Kang, Dale Karr, Yasumi Kawamura, Alan Klanac, Sean O'Neil, Enrico Rizzuto, Angelo Teixeira, Koichi Yoshida. Design Principles and Criteria. Report of Committee IV.1 // Proc. of $18^{\text {th }}$ ISSC. 2012. Rostock (Gernany), 2012. Vol. 1. P. 435-506.

44. Rizzuto, E., Downes, J., Radon, M., Egorov, G., Kawamura, Y., $O^{\prime} N e i l$, S., Skjong, R., Teixeira A. Design Principles and Criteria. Report of Committee IV.1 // Proc. of 19 th ISSC. 2015. Cascais (Portugal), 2015. Vol. 1. P. 415-458.

45. Collette, M., Zhan, Z., Zhu, L., Zanic, V., Okada, T., Arima, T., Skjong, R., Jeong, H.K., Egorov, G. Design Principles and Criteria. Report of Committee IV.1 // Proc. of $20^{\text {th }}$ ISSC. 2018. Liege (Belgium) \& Amsterdam (The Netherlands), 2018. Vol. 1 (Edited by M.L. Kaminski and P. Rigo). P. 549-607.

Стаття надійшла до редакиії 06.06.2021

Посилання на статтю: Егоров А.Г. О научно-практическом наследии профессора Геннадия Вячеславовича Егорова // Вісник Одеського національного морського університету: Зб. наук. праць, 2021. № 2(65). C. 12-46. DOI 10.47049/ 2226-1893-2021-2-12-46.

Article received 06.06.2021

Reference a JournalArtic: A. Egorov About science-practical heritage of professor Gennadiy Egorov // Herald of the Odessa national maritime university, 2021. 2(65). 12-46. DOI 10.47049/ 2226-1893-2021-2-12-46. 